\title{
The modeled distribution of corals and sponges surrounding the Salas y Gómez and Nazca ridges with implications for high seas conservation
}

\author{
Samuel Georgian ${ }^{\text {Corresp., } 1}{ }^{1}$, Lance Morgan ${ }^{1}$, Daniel Wagner ${ }^{2}$ \\ ${ }^{1}$ Marine Conservation Institute, Seattle, Washington, United States \\ 2 Center for Oceans, Conservation International, Arlington, Virginia, United States of America \\ Corresponding Author: Samuel Georgian \\ Email address: samuel.georgian@marine-conservation.org
}

The Salas y Gómez and Nazca ridges are two adjacent seamount chains off the west coast of South America that collectively contain more than 110 seamounts. The ridges support an exceptionally rich diversity of benthic and pelagic communities, with the highest level of endemism found in any marine environment. Despite some historical fishing in the region, the seamounts are relatively pristine and represent an excellent conservation opportunity to protect a global biodiversity hotspot before it is degraded. One obstacle to effective spatial management of the ridges is the scarcity of direct observations in deeper waters throughout the region and an accompanying understanding of the distribution of key taxa. Species distribution models are increasingly used tools to quantify the distributions of species in data-poor environments. Here, we focused on modeling the distribution of demosponges, glass sponges, and stony corals, three foundation taxa that support large assemblages of associated fauna through their creation of complex habitat structures. Models were constructed at a $1 \mathrm{~km}^{2}$ resolution using presence and pseudoabsence data, dissolved oxygen, nitrate, phosphate, silicate, aragonite saturation state, and several measures of seafloor topography. Highly suitable habitat for each taxa was predicted to occur throughout the Salas y Gómez and Nazca ridges, with the most suitable habitat occurring in small patches on large terrain features such as seamounts, guyots, ridges, and escarpments. Determining the spatial distribution of these three taxa is a critical first step towards supporting the improved spatial management of the region. While the total area of highly suitable habitat was small, our results showed that nearly all of the seamounts in this region provide suitable habitats for deep-water corals and sponges and should therefore be protected from exploitation using the best available conservation measures. 
1 The modeled distribution of corals and sponges surrounding the Salas y Gómez and Nazca ridges

2 with implications for high seas conservation

3

4

5

6

8

Samuel E Georgian ${ }^{1}$, Lance Morgan ${ }^{1}$, Daniel Wagner ${ }^{2}$

${ }^{1}$ Marine Conservation Institute, Seattle, WA, USA

${ }^{2}$ Center for Oceans, Conservation International, Arlington, VA, USA

Corresponding Author:

Samuel Georgian ${ }^{1}$

1914 N 34th Street Ste 400, Seattle, WA, 98103, USA

Email address: Samuel.Georgian@marine-conservation.org

\section{Abstract}

The Salas y Gómez and Nazca ridges are two adjacent seamount chains off the west coast of South America that collectively contain more than 110 seamounts. The ridges support an exceptionally rich diversity of benthic and pelagic communities, with the highest level of endemism found in any marine environment. Despite some historical fishing in the region, the seamounts are relatively pristine and represent an excellent conservation opportunity to protect a global biodiversity hotspot before it is degraded. One obstacle to effective spatial management of the ridges is the scarcity of direct observations in deeper waters throughout the region and an accompanying understanding of the distribution of key taxa. Species distribution models are increasingly used tools to quantify the distributions of species in data-poor environments. Here, we focused on modeling the distribution of demosponges, glass sponges, and stony corals, three foundation taxa that support large assemblages of associated fauna through their creation of complex habitat structures. Models were constructed at a $1 \mathrm{~km}^{2}$ resolution using presence and pseudoabsence data, dissolved oxygen, nitrate, phosphate, silicate, aragonite saturation state, and several measures of seafloor topography. Highly suitable habitat for each taxon was predicted to occur throughout the Salas y Gómez and Nazca ridges, with the most suitable habitat occurring in small patches on large terrain features such as seamounts, guyots, ridges, and escarpments. Determining the spatial distribution of these three taxa is a critical first step towards supporting the improved spatial management of the region. Our results showed that nearly all of the seamounts in this region provide suitable habitats for deep-water corals and sponges and should therefore be protected from exploitation using the best available conservation measures.

\section{Introduction}

The Salas y Gómez and Nazca ridges are two adjacent seamount chains stretching more than 2,900 km off the coasts of Peru and Chile (Figure 1) (reviewed in Wagner et al. 2021). Combined, the ridges contain more than 110 seamounts that were created between 2-27 million years ago by a geological hotspot located on the western edge of the Salas y Gómez Ridge (Parin 
41 et al. 1997; Steinberger 2002). The limited exploration that has been accomplished along the

42

43

44

45

46

47

48

49

50

51

52

53

54

55

56

57

58

59

60

61

62

63

64

65

66

67

68

69

70

71

72

73

74

75

76

77

78

79

80 ridges has revealed exceptionally high biodiversity as well as unusually high endemism, due in part to its isolation from South America by the Humboldt Current System and the Atacama Trench (Parin 1991; Comité Oceanográfico Nacional de Chile 2017). More than 40\% of known fish and invertebrate species are endemic to the region, one of the highest levels of marine endemism in the world (Parin et al. 1997; Friedlander et al. 2016). New species have frequently and recently been discovered on the ridges (e.g., Andrade et al. 2014; Sellanes et al. 2019; Shepherd et al. 2020; Diaz-Diaz et al. 2020), indicating that many new species remain to be discovered. The waters surrounding the Salas y Gómez and Nazca ridges provide important feeding grounds and migratory pathways for an array of important species, including billfish, sharks, sea turtles, seabirds, and marine mammals (Weichler et al. 2004; Shillinger et al. 2008; Yañez et al. 2009; Hucke-Gaete et al. 2014; CBD 2017; Serratosa et al. 2020). On the seamounts and neighboring island habitats, diverse benthic communities form around shallow-water, mesophotic (Easton et al. 2019), and deep-water coral and sponge reefs (Hubbard and Garcia 2003; Easton et al. 2019; Friedlander et al. in press).

Deep-water corals and sponges are critical foundation species found in every ocean basin. The complex, three-dimensional habitat structures they produce support thousands of associated species including other invertebrates and commercially important fish (Rogers 1999; Costello et al. 2005; Cordes et al. 2008; Kenchington et al. 2013). In addition to habitat creation, corals and sponges provide other critical ecosystem services including the alteration of local current regimes (Dorschel et al. 2007; Mienis et al. 2009), carbon cycling and long-term sequestration (van Oevelen et al. 2009; Kahn et al. 2015), and nutrient cycling (Wild et al. 2008; Tian et al. 2016). Deep-water corals and sponges are also being increasingly used as avenues for research purposes ranging from biomedical research (e.g., Hill 2003; Müller et al. 2004) to reconstructing paleoclimate archives of climate change, pollution, and nutrients (Smith et al. 2000; Williams et al. 2006; Cao et al. 2007). The slow growth rates (Prouty et al. 2011), extreme longevity (Roark et al. 2009; Fallon et al. 2010), and life history strategies (e.g., low recruitment; Doughty et al. 2014) make these taxa extremely sensitive to anthropogenic disturbance, and the recovery of damaged communities may take many decades, centuries, or even longer (see Ramierz-Llodra et al. 2011; Baco et al. 2019). Considering the extreme logistical difficulties and costs associated with restoration efforts in these remote habitats (van Dover et al. 2014), improved conservation measures are urgently needed to protect these fragile ecosystems before long-term damage occurs.

Like most marine biodiversity hotspots, the Salas y Gómez and Nazca ridges are threatened by a variety of ongoing or imminent anthropogenic disturbances, including commercial fishing, marine debris and plastic pollution, seabed mining, and climate change (reviewed in Wagner et al. 2021). Despite these threats and the clear biological value of the ridges, protecting their sensitive benthic communities from anthropogenic disturbance is a complex challenge. Over $73 \%$ of the ridges are located within areas beyond national jurisdiction (ABNJ), commonly known as the high seas, where no one country has sole management

Peer) reviewing PDF | (2021:02:58211:1:1:NEW 14 Jul 2021) 
81 responsibility and hence international cooperation is necessary. While the portions of the ridge

82 located within the Chilean and Peruvian economic exclusive zones (EEZs) have several

83 established marine protected areas (MPAs) (MPAtlas 2021), the high seas portions of the ridges

84 are more loosely regulated by intergovernmental agencies including the International Seabed

85 Authority (ISA), the International Maritime Organization (IMO), the Inter-American Tropical

86 Tuna Commission (IATTC), and the South Pacific Regional Fisheries Management Organisation

87 (SPRFMO), which regulate seabed mining, shipping, and fishing, respectively. Despite United

88 Nations guidance and ongoing negotiations to better protect vulnerable marine ecosystems

89 (VMEs) on the high seas (UNGA 2007; Rogers and Gianni 2010), there is no legal mechanism to

90

91

92

93

94

95

96

97

98

99 establish high seas MPAs that are applicable to all States or sectors. Industrial fishing occurs in an estimated $48 \%$ of $\mathrm{ABNJ}$, with fisheries pushing into deeper waters each year as stocks deplete in shallower waters (Visalli et al. 2020). Commercial fishing in waters surrounding the Salas y Gómez and Nazca ridges has been relatively limited historically (Wagner et al. 2021), providing a unique opportunity to protect this diverse region before it is irrevocably damaged. However, effecting strong protection in ABNJ is difficult due to the lack of clear legal or political mechanisms, competing interests, and lack of sufficient data in lesser-explored regions (Gjerde et al. 2021).

Species distribution models, also referred to as habitat suitability models, are important tools that help characterize the distribution and niche of taxa in data-poor regions. These models can be particularly useful for deep-water taxa on the high seas, where extremely limited surveys have occurred relative to shallow-water coastal areas (Fujioka and Halpin 2014; Ortuño Crespo et al. 2019), and data availability is a considerable obstacle to improved conservation management and scientific advancement (Vierod et al. 2014; Wagner et al. 2020). Species distribution models statistically couple the known distribution of species with relevant environmental parameters to predict niche and distribution in unsurveyed geographic regions or under varying environmental conditions (Guisan and Zimmermann 2000; Miller 2010). Quantifying the biogeographic distribution of ecologically important or threatened species is critical for designing and implementing management plans, shaping future research and exploration efforts, and assessing past, present, and future anthropogenic impacts. Increasingly, species distribution models are being developed specifically to inform marine conservation and management (e.g., Rowden et al. 2017; Georgian et al. 2019) or to predict responses to recent anthropogenic disturbances (e.g., Georgian et al. 2020). Models have been successfully developed for a large variety of benthic taxa, including global models for stony corals (Davies and Guinotte 2011), black corals (Yesson et al. 2017), octocorals (Yesson et al. 2012), and gorgonian corals (Tong et al. 2013), as well as large-scale regional sponge models (e.g., Knudby et al. 2013; Chu et al. 2019). Given their status as foundation species, and the frequent classification of these taxa as indicators of VMEs, which SPRFMO and other fishery management organizations are tasked with identifying and protecting (e.g., Penney et al. 2009), it is critical to quantify their distribution in threatened areas. 
An improved understanding of the spatial distribution of key taxa throughout the Salas $y$ Gómez and Nazca ridges is necessary for the evidence-based conservation management of the region. The suitability modeling in this study will inform ongoing efforts to identify and prioritize key conservation targets along the ridges (see Wagner et al. 2021), reinforcing the increasingly clear need to protect sensitive benthic fauna in the region from further exploitation and disturbance from anthropogenic sources. In addition to conservation planning, these models will also support future expedition planning, and will improve our understanding of the niche of cold-water corals and sponges throughout the region.

\section{Materials \& Methods}

\section{$\underline{\text { Study Area }}$}

The study area encompassed a large region $\left(15,991,101 \mathrm{~km}^{2}\right)$ of the southeast Pacific Ocean centered on the Salas y Gómez and Nazca ridges off the coasts of Peru and Chile (Figure 1). This area contains 755 seamounts and guyots covering a total area of $561,452 \mathrm{~km}^{2}(3.5 \%$ of the total area; geomorphology data from Harris et al. 2014). The region includes an area that has been recognized as an Ecologically or Biologically Significant Marine Area (EBSA) by the Conference of the Parties to the Convention of Biological Diversity (CBD 2014). The EBSA extends around the ridges (Figure 1) and includes roughly 285 seamounts and guyots covering a total area of $294,225 \mathrm{~km}^{2}$ (17.2\% of the EBSA area). The region is bounded on the eastern side by the Atacama Trench, which along with the Humboldt Current System isolates the ridges from South America (Von Dassow and Collado-Fabbri 2014). The Nazca Ridge is comprised primarily of a large plateau, while the Salas y Gómez Ridge is mostly comprised of a series of smaller seamounts, escarpments, and ridge features (Supplemental Figure 21). Seamounts and features farther east along the ridges are progressively older and deeper (Rodrigo et al. 2014). Closer to the South American coast, a series of deep-water canyons extends into the Atacama Trench, while farther offshore the terrain is dominated by a series of large spreading ridges as well as smaller seamounts, ridges, and escarpments. The study area is primarily categorized as abyssal, with the Atacama Trench extending into hadal environments and small areas along the coasts, islands, and shallower seamounts extending upwards onto the slope and shelf (Supplemental Figure 22).

\section{Occurrence Records}

Geo-referenced coral and sponge records were obtained from the Ocean Biodiversity Information System (OBIS 2020) and the NOAA Deep-Sea Coral and Sponge Database (NOAA 2020), and supplemented with records from recent expeditions to the area (J Sellanes and E Easton, 2020, unpublished data). All records were obtained as presence-only records, with duplicate records removed prior to analysis. The bulk of records were focused on the Salas $y$ Gómez and Nazca ridges, with another cluster of records in the neighboring Juan Fernández Islands region. We chose to focus on three higher taxonomic groupings that are often key 
160 foundation species on seamounts: stony corals (Order: Scleractinia, $n=233$ ), demosponges

161 (Class: Demospongiae, $n=275$ ), and glass sponges (Class: Hexactinellida, $n=134$ ) (Supplemental

162 Tables 3-5).

163

164

$\underline{\text { Pseudoabsence Records }}$

165

Species distribution models are ideally constructed using either presence-absence or

166 abundance datasets (Winship et al. 2020). However, obtaining high-quality, true absence data is

167 often difficult or impossible in remote environments, and particularly for deeper-water species.

168

169

170

171

172

173

174

175

176

177

178

179

180

181

182

183

184

185

186

187

188

189

190

191

192

193

194

195

196

197

198

199

Even when absences are recorded, they may reflect the lack of systematic observations throughout the entire study area rather than true absence (particularly given the narrow field of view of most submersibles or towed camera arrays and similar issues with other sampling techniques such as tows or dredges). Inferring suitable habitat from absence data may also be misleading due to dispersal limitation, biotic interactions, or historical disturbances (e.g., Hirzel et al. 2002). Researchers are increasingly developing methods that account for the lack of true absence data by using sophisticated methods to produce better-than-random pseudoabsence or background data (e.g., Iturbide et al. 2015).

One of the primary limitations with species distribution models, and especially with presence-only models, is sampling bias in the occurrence data (Kramer-Schadt et al. 2013; Syfert et al. 2013). Although often unaccounted for, sampling bias can introduce significant errors into models, affecting both their performance and ecological interpretability (e.g., Syfert et al. 2013). We chose to reduce the effects of sampling bias by creating pseudoabsence data that has the same bias found in the presence data (Elith et al. 2010; Huang et al. 2011; Fitzpatrick et al. 2013). To mirror the sampling bias that likely exists in our presence records, we created a twodimensional kernel density estimate of sampling effort based on the presence locations for each taxon (Supplemental Figures 6-8). Pseudoabsence records $(\mathrm{n}=10,000)$ were sampled using this density estimate as a probability grid, resulting in a set of unique, sample-bias corrected pseudoabsences for each taxon.

\section{Environmental Data}

Within the study area, a suite of 44 environmental variables known to influence the distribution of corals and sponges were constructed for use in models (Table 1). Bathymetry for the study area were obtained from the SRTM30+ dataset (Becker et al. 2009; Sandwell et al. 2014) at a native resolution of $0.0083^{\circ}$ (approximately $1 \mathrm{~km}$ ) and used in the creation of several additional layers.

A number of terrain metrics were derived from this bathymetry layer to define the shape of the seafloor. Slope, roughness, aspect, general curvature, cross-sectional curvature, and longitudinal curvature were calculated using the ArcGIS (v10.8, ESRI) toolkit 'DEM Surface Tools' (v2; Jenness 2004, Jenness 2013a). Slope was measured in degrees and calculated using the 4-cell method (Jones 1998). Aspect represents the compass direction of the steepest slope and was converted to an index of eastness using a sine transformation and an index of northness

Peerj reviewing PDF | (2021:02:58211:1:1:NEW 14 Jul 2021) 
200

201

202

203

204

205

206

207

208

209

210

211

212

213

214

215

216

217

218

219

220

221

222

223

224

225

226

227

228

229

230

231

232

233

234

235

236

237

238

using a cosine transformation. Curvature metrics assess the likely flow of water across a feature, with positive values generally indicating convex features that cause water to accelerate and diverge, in contrast to concave features where water would be expected to decelerate and converge. Roughness is a measure of topographical complexity, calculated here as the ratio of surface area to planimetric area, with more positive values indicating more complex terrain. The Topographic Position Index (TPI) was calculated using the toolkit Land Facet Corridor Designer (v1.2; Jenness et al. 2013b). TPI assesses the relative height of features compared to the surrounding seafloor, with positive areas indicating locally elevated features and negative values indicating depressions. TPI is scale dependent, and was calculated at scales of $1,000 \mathrm{~m}, 5,000 \mathrm{~m}$, $10,000 \mathrm{~m}, 20,000 \mathrm{~m}, 30,000 \mathrm{~m}, 40,000 \mathrm{~m}$, and 50,000 m. Finally, the Vector Ruggedness Measure (Hobson 1972; Sappington et al. 2007), which calculates terrain heterogeneity, was calculated with a neighborhood size of $3,5,7,9,15,17$, and 21 using the Benthic Terrain Modeler (v3.0; Walbridge et al. 2018).

To complement the suite of terrain metrics, large-scale geomorphological features expected to provide suitable habitat for corals and sponges were obtained from Harris et al. (2014), including seamounts, guyots, canyons, ridges, spreading ridges, plateaus and escarpments. See Supplemental Figure 21 for a map of geomorphological features in the study area.

Data describing benthic conditions at the seafloor were obtained from the World Ocean Atlas (v2; 2013), including temperature, dissolved oxygen, salinity, nitrate, phosphate, and silicate. Carbonate data including dissolved inorganic carbon (DIC), total alkalinity, and the saturation states of calcite and aragonite, were obtained from Steinacher et al. (2009). Current data describing regional horizontal and vertical current velocities were obtained from the Simple Ocean Data Assimilation model (SODA v3.4.1; Carton et al. 2008). Particulate organic carbon (POC) flux to the seafloor was obtained from Lutz et al. (2007). Raw benthic data layers were transformed to match the extent and resolution of the other environmental variables using the upscaling approach developed by Davies and Guinotte (2011). This upscaling technique incorporates bathymetry data to approximate conditions at the seafloor and has previously been demonstrated to work effectively on both global and regional scales for a variety of data (Yesson et al. 2012; Georgian et al. 2019). The upscaled WOA data (dissolved oxygen, nitrate, phosphate, and silicate) was compared to quality-controlled bottom-water bottle data from the Global Ocean Data Analysis Project (GLODAP v2.2019) to assess how much error may have been present in the raw WOA datasets or introduced via our upscaling approach (see Supplemental Figure 23).

Surface conditions were assessed as chlorophyll $a$ and mean sea surface temperature data obtained from the Aqua MODIS program (Aqua MODIS 2018). Both layers were calculated as the mean value from 2002-2016 at a native resolution of $4 \mathrm{~km}$, and resampled to match the extent and resolution of the other environmental layers with no additional interpolation.

\section{$\underline{\text { Modeling Techniques }}$}


239

240

241

242

243

244

245

246

247

248

249

250

251

252

253

254

255

256

257

258

259

260

261

262

263

264

265

266

267

268

269

270

271

272

273

274

275

276

277

278

Models were constructed using four different techniques that have proven successful in modeling the distribution of cold-water corals and sponges: Boosted Regression Tree (BRT), Generalized Additive Models (GAM), Maximum Entropy (Maxent), and Random Forest (RF). For each modeling technique, the sampling-bias corrected set of pseudoabsences $(n=10,000)$ was used in place of either true absences or random pseudoabsences. Each model outputs a habitat suitability score between $0-1$, with higher scores indicating more suitable habitat. While often erroneously referred to as the probability of occurrence, this score does not represent a true probability of occurrence in presence-only models due to the lack of true absences and nonsystematic observation of the study area. The refinement of model parameters, final model, model evaluations, and model outputs (e.g., variable importance and response curves) were completed using 'biomod2' (Thuiller et al. 2016), 'gbm' (Ridgeway 2004), 'dismo' (Hijmans et al. 2017), 'mgcv' (Wood and Wood 2015), and 'randomForest' (Liaw and Wierner 2002) in R (v3.6.1; R Core Team 2019).

Boosted Regression Tree (BRT) models rely on binary splits in a regression-tree structure to define the response of species occurrence or abundance to environmental variables (Elith et al. 2008), and have been successfully used to model the distribution of deep-sea fauna (e.g., Rowden et al. 2017; Georgian et al. 2019). The minimum number of trees was set at 1,000, and a Bernoulli distribution of the presence-pseudoabsence data was assumed. Tree complexity was set to three to allow limited interactions between terms.

Maxent (Phillips et al. 2006) is a machine learning, presence-only modeling algorithm that has been shown to outperform other presence-only models (Elith et al. 2006; Tittensor et al. 2009) and even presence-absence models (Reis et al. 2011). Default model settings were used except the maximum number of iterations was increased to 500 to ensure that models converged. In addition, the regularization parameter (default of $\beta=1$ ) was experimentally tested using values of $\beta=1-10$. Regularization is a smoothing function that controls the complexity of models, with higher values resulting in simpler models with fewer parameters. An ultimate value of $\beta=5$ was chosen for all taxa based on the performance of preliminary models. Previous Maxent modeling of cold-water corals has shown that increasing $\beta$ improves model performance in areas or conditions outside of the training data, essentially by preventing the model from overfitting to its training data (Georgian et al. 2014).

A Generalized Additive Model (GAM) is a type of generalized linear model that employs smoothing functions for each explanatory variable (Hastie and Tibshirani 1986). GAM has frequently been used to model the distribution and niche of a variety of marine species including corals and sponges (e.g., Rooper et al. 2014). A binomial distribution of the presencepseudoabsence data was assumed. Various types of smoothers and degrees of freedom allowed were explored in preliminary models, resulting in a thin plate regression spline smoothing function with 12 degrees of freedom used for all variables and modeling runs. Testing higher degrees of freedom (ranging from 4-15) resulted in small improvements in model performance but increased computational time, with no significant model improvements above 12 degrees of freedom (in general agreement with the findings of Wood 2017). 
279

280

281

282

283

284

285

286

287

288

289

290

291

292

293

294

295

296

297

298

299

300

301

302

303

304

305

306

307

308

309

310

311

312

313

314

315

316

317

318

Random Forest (RF) models (Breiman 2001) are a classification or regression, tree-based algorithm that relies on a random selection of explanatory variables and an internal bootstrapping metric to produce and then combine a large number of trees. Default parameters were used except the number of trees was increased to 501 and tree depth was limited to a value of ten to prevent overfitting to the training data. Various tree depths (1-20) were investigated in preliminary models, and a tree depth of ten was ultimately selected as it appeared to improve model performance while preventing models from strongly overfitting to the training data. Tuning tree depth appropriately has been shown to improve model performance without significantly affecting computational time (Duroux and Scornet 2018), with larger than default values often yielding the best results (Segal 2003). It should be noted however that other studies have produced better results by limiting tree depth (Nadi and Moradi 2019), suggesting that the correct tuning value may be dependent on the dataset used as well as how other model

parameters are tuned in conjunction. The optimal value of 'mtry' was also experimentally altered in preliminary models, however, the default value (the square root of the number of explanatory variables) consistently performed well and was therefore used across all model runs.

Each modeling approach (BRT, Maxent, GAM, and RF) is fundamentally distinct and depends on different structures and assumptions. Therefore, each will produce different habitat suitability maps that may reflect tradeoffs in various aspects of model performance, making it difficult to accurately determine which, if any, model type is superior (Robert et al. 2016). To create a more robust final model, we generated an ensemble model for each taxon based on a performance-weighted average of habitat suitability scores from each model type. The BRT, Maxent, GM, and RF model for each taxon were combined using a weighted average of habitat suitability, with weights based on model performance (AUC scores).

\section{Model Testing}

Models were tested using a ten-fold cross-validation procedure that randomly partitioned occurrences into $20 \%$ test data and $80 \%$ training data. Metrics of model performance were calculated for each run and averaged across all ten runs, however, final models were trained using the entire dataset. Model performance was assessed through a combination of Area Under the Curve (AUC) and the true skill statistic (TSS). AUC is a threshold-independent performance measure that in presence-only models indicates the probability that the model correctly ranks occurrences over background locations. A random model has a theoretical AUC of 0.5, and while the maximum AUC is generally unknowable in presence-only models it is always less than 1 (Wiley et al. 2003; Phillips et al. 2006). The TSS metric is similar to the conventionally reported kappa, but is independent of species prevalence as well as the size of the validation dataset (Allouche et al. 2006). TSS ranges from -1 to +1 with negative values indicating more random performance and positive values indicating better performance. To fine-tune model parameters (see above), the Akaike Information Criterion (AIC) was also used to assess model performance. AIC helps assess the tradeoff between goodness of fit and simplicity of models, and is therefore commonly used for model selection. A similar ten-fold cross validation approach 
319 was used to estimate the spatial uncertainty of the models by randomly withholding $20 \%$ of 320 occurrence and pseudoabsence data from model construction with replacement between runs.

321 Uncertainty was then assessed as the standard deviation of habitat suitability scores across all ten

322 model runs. This approach does not account for all possible sources of uncertainty, but provides

323 a useful spatial measure of how sensitive the model is to the sampling of occurrence data and the 324 construction of the pseudoabsence dataset.

325

326

Variable Selection

327

The inclusion of highly correlated variables in species distribution models can reduce

328 model performance and make the results more difficult to interpret ecologically (Tittensor et al. 2009; Huang et al. 2011). Therefore, we employed a variable selection process to refine our original list of 44 environmental layers to a more parsimonious list of less-correlated variables.

331

332 Variable selection was based on 1) preliminary model testing including predicted variable importance and impact on overall model performance for BRT, Maxent, GAM, and RF models,

333 2) correlation and clustering among variables, and 3) known biological importance for each taxon. When variables were highly correlated (Pearson's correlation coefficients $>0.7$ ) and clustered together (see Supplemental Figures 1 and 2), preference was given to the variable that exhibited the best model performance, was less-correlated with other variables, clustered more independently, or was considered to be more biologically relevant.

338

Depth was artificially removed despite high model performance due to its high

339 correlation with several, more biologically-relevant variables. The saturation state of aragonite

340

341 $\left(\Omega_{\mathrm{A}}\right)$ was included for stony corals due to moderate to high performance in preliminary models and known importance for structuring cold-water coral distributions (e.g., Georgian et al. 2014; Georgian et al. 2016). Silicate concentration was included for both demosponges and glass sponges due to the inclusion of silicate in their skeletal structures and high performance in

344 preliminary models. POC was retained despite relatively high correlations with both silicate (-

345

346

347 $0.784)$ and $\Omega_{\mathrm{A}}(0.769)$ due to the known biological importance of all three variables and performance in preliminary models. However, it should be noted that ecological interpretations can be difficult when variables are highly correlated.

348

The final variable set included eight variables for each taxon, including dissolved oxygen,

350

351

352

353

354

355

356

357 nitrates, phosphates, slope, TPI calculated at a scale of 40,000 m (TPI-40000), VRM calculated with a neighborhood size of 21 (VRM-21), POC, silicate (demosponge and glass sponges only), and $\Omega_{\mathrm{A}}$ (stony corals only). Within the final variable set for each taxon, the highest correlation among variables was -0.684 ( $\mathrm{POC}$ and silicate), and variables clustered relatively independently compared with the original set (Figure 2 and Supplemental Table 1).

\section{Results}

Model Performance 
358

359

360

361

362

363

364

365

366

367

368

369

370

371

372

373

374

375

376

377

378

379

380

381

382

383

384

385

386

387

388

389

390

391

392

393

394

395

396

397

The models performed well across all taxa and modeling algorithms (Table 2). The tenfold cross-validation procedure produced test AUC scores that were generally above 0.9 , with a lowest score of 0.837 (RF model for demosponges). Test TSS scores were similarly high, with an average TSS score of 0.809 across all model types and taxa. Test scores did not change considerably among different cross-validation runs, suggesting that ten runs were sufficient to capture the variation caused by withholding different testing data. Glass sponge models performed slightly worse across all modeling types (average test AUC of 0.905 and training AUC of 0.925), followed by demosponges (average test AUC of 0.932 and training AUC of 0.942). Stony corals performed the best by a small margin with an average test AUC of 0.942 and training AUC of 0.952.

Test data revealed that GAM and Maxent models consistently performed slightly better than BRT and RF models. When looking at the evaluation metrics for the final models built using all available training data, RF consistently outperformed the other approaches, consistently having the highest AUC and TSS scores. However, when looking at test scores during crossvalidation, RF scores dropped considerably, suggesting that RF models were slightly overfitting to the training data despite optimization of model parameters. In contrast, Maxent models, which generally performed slightly worse than RF models when using training data, had little to no decrease in scores when using testing data, in some cases even performing better against testing data. This suggests that the optimization of the Maxent regularization parameter $(\beta=5$, default $=1)$ was successful in reducing model complexity to appropriate levels without a large effect on overall model performance. Testing and training scores were similar for BRT and GAM models, with a very slight decrease in most testing scores. BRT and RF models generally had the lowest uncertainty (Supplemental Figures 24-35) compared to GAM and Maxent models, although GAM uncertainty was highly spatially restricted to very small areas of highly suitable habitat.

The full ensemble models performed well, with an AUC of 0.988 for demosponges, 0.968 for glass sponges, and 0.973 for stony corals. It is interesting that the demosponge ensemble model performed the best by a small margin, when the individual models performed slightly worse than the models for stony corals. This suggests that the ensemble modeling approach was successful in reducing potential structural inadequacies, lack of ideal model optimization, or bias in each model type that may affect the outputs (Robert et al. 2016). In general, the scores for the ensemble models suggest that they outperformed GAM, Maxent, and BRT models, but performed slightly worse than the RF model. However, this is likely because RF models were overfitting slightly, producing artificially elevated training scores. Collectively, the performance metrics suggest that the ensemble models were the best for each taxon.

\section{Distributions}

For all three taxa, areas with high predicted habitat suitability were largely restricted to small pockets clustered around the Salas y Gómez and Nazca ridges, the eastern portion of the Foundation Seamount Chain, and the waters around the Juan Fernández Islands (Figures 3-5). Glass sponges and stony corals also had strips of low-moderate suitability along the South 
398

399

400

401

402

403

404

405

406

407

408

409

410

411

412

413

414

415

416

417

418

419

420

421

422

423

424

425

426

427

428

429

430

431

432

433

434

435

436

437

American coast and along the west flank of the Atacama Trench. Stony corals models also predicted low-moderate suitability on a large spreading ridge along the East Pacific Rise, although there were few highly suitable areas (see Supplemental Figure 21). Within the Salas y Gómez and Nazca ridges, suitability predictions were remarkably similar among the three taxa, with highly suitable habitat coinciding with the flanks and summits of most seamount, knoll, and ridge features (see Figure 6). However, glass sponges appeared to have higher suitability predicted on the steeper sides of large seafloor features, while demosponges and stony corals were predicted to occur on the flanks and especially on the summits of the same features.

When the predicted distribution of each taxa was assessed against the large-scale geomorphological classifications (Harris et al. 2014, see Supplemental Figure 21), a clear preference for escarpments, ridges, seamounts, guyots, and plateaus (primarily along the Nazca Ridge) emerged (Supplemental Table 2). BRT and RF models typically predicted narrow distributions clustered almost exclusively on seamounts and other large terrain features, while Maxent and GAM also predicted areas of low-moderate suitability in bands along the coast, spreading ridges, and smaller-scale terrain features throughout the region (Supplemental Figures 9-20). While the highly suitability regions were remarkably similar among modeling types, structural differences or assumptions in each model type did affect the overall suitability predictions, lending additional support for the creation and use of ensemble models rather than relying on a single model. It should be noted that model uncertainty was generally highest in areas with higher predicted habitat suitability (Supplemental Figures 24-35), as well as in more coastal areas, suggesting that additional field surveys may improve models in these areas.

Niche

The niche of each taxa was assessed via a combination of variable contribution to the models (Table 3), response curves showing how predicted suitability changes over a range of environmental conditions (Figure 7), and bean plots showing the environmental conditions occurring in the known distribution of each taxa compared to background conditions (Supplemental Figures 3-5).

Terrain metrics consistently contributed a considerable amount of information in each model. Across all model types for demosponges, slope contributed an average of $2 \%$ of information, TPI- 40,000 contributed an average of $45.3 \%$, and VRM- 21 contributed an average of $9.9 \%$. For glass sponges, slope contributed an average of 9.4\%, TPI-40,000 contributed an average of $4.0 \%$, and VRM- 21 contributed an average of $4.5 \%$. For stony corals, slope contributed an average of $0.6 \%$, TPI- 40,000 contributed an average of $12.3 \%$, and VRM-21 contributed an average of $2.7 \%$. Considered jointly, terrain comprised between $15.5-57.3 \%$ of information for each taxon, suggesting that the shape of the seafloor is an important component of their niche. Response curves and bean plots suggest that stony corals and demosponges have a clear preference for elevated TPI values (indicating large-scale elevated features). All three taxa show a preference for elevated VRM values (indicating more varied terrain). Interestingly, VRM-21 correlated and clustered with seamounts (Pearson's coefficient of 0.5; Supplemental

Peerj reviewing PDF | (2021:02:58211:1:1:NEW 14 Jul 2021) 
438 Figure 1 and 2), indicating that at this scale, VRM-21 was a likely an indicator of features similar 439 in topography to seamounts, guyots, and knolls. Bean plots showed that the known distribution

440 of all three taxa coincides with higher slope values of approximately 5-20 degrees compared with 441 background data, however, response curves indicated a more complex relationship.

442 Demosponges exhibited a small preference for elevated slopes, while glass sponges had a large 443 preference for slopes up to approximately 15 degrees, and then a lower preference for steeper slopes. Stony corals had a negative affinity for slopes steeper than $5^{\circ}$.

Silicate was the highest performing variable for glass sponge models (average

447

448

449

450

451

452

453

454

455

456

457

458

459

460

461

462

463

464

465

466

467

468

469

470

471

472

473

474

475

476

477

contribution of 56.2 across model types), and the second highest for demosponges (average contribution of $17.9 \%$ across model types). Response curves indicated that both sponge taxa have a large drop-off in predicted suitability once silicate values exceed approximately 30-40 $\mu \mathrm{mol} \mathrm{l}^{-1}$, and bean plots show that both taxa occur at lower than expected silicate values relative to the background environment. It should be noted that silicate had high correlations with other retained variables, including POC (Pearson's coefficient of -0.684) and nitrates (Pearson's coefficient of 0.538 ), which complicates the ecological interpretation of these results.

For stony corals, $\Omega_{\mathrm{A}}$ contributed by far the most information in each model type with an average of $68.3 \%$ across all models. A clear preference in both response curves and bean plots for elevated $\Omega_{\mathrm{A}}$ values above 1.5 indicated a need for a supersaturated environment. All three taxa were also moderately-highly influenced by POC, with response curves indicating a small spike in suitability between $0-10 \mathrm{~g} \mathrm{C} \mathrm{m}^{-2}$, and then a rapid decrease in suitability at higher concentrations. However, an analysis of the bean plots indicates that $\mathrm{POC}$ values $>5 \mathrm{~g} \mathrm{C} \mathrm{m}^{-2}$ are rare in the study area, and that all three taxa occur at higher than expected concentrations compared with background values.

Dissolved oxygen, nitrate, and phosphate concentrations were only moderately important in the models for each taxon, generally only entering the top three variables in GAM models, which typically included more moderate contributions from all variables rather than receiving large contributions for a few variables. Response curves indicated that glass sponges preferred elevated dissolved oxygen concentrations, while demosponges and stony corals did not have a clear response. Both sponge taxa appeared to moderately prefer higher nitrate values, while stony corals indicated a small preference for lower values. All three taxa exhibited a moderate preference for lower phosphate concentrations.

\section{Discussion}

\section{$\underline{\text { Overview }}$}

In order to better inform the spatial management of fisheries and other human activities in the Salas y Gómez and Nazca ridges, we developed ensemble species distribution models for three taxa that are frequently classified as indicator taxa for VMEs (e.g., Penney et al. 2009; Parker et al. 2009): demosponges, glass sponges, and stony corals. These taxa act as critical foundation species in deep waters due to their habitat creation and other critical ecosystem

Peer] reviewing PDF | (2021:02:58211:1:1:NEW 14 Jul 2021) 
478 services (Roberts et al. 2009). These areas are VMEs due to their susceptibility to disturbance 479 based on the fragility, rarity, functional significance, and life history traits of their members 480 (FAO 2009). The United Nations require that states and associated intergovernmental agencies 481 identify and protect VMEs, including the closure of fisheries when necessary (UNGA 2007). A 482 better understanding of the spatial distribution and niche of key VME taxa is a critical step 483 towards enacting protection for these fragile and diverse habitats.

484

485

486

487

488

489

490

491

492

493

494

495

496

497

498

499

500

501

502

503

504

505

506

507

508

509

510

511

512

513

514

515

516

517

The models show that only a small portion of the total study area contained moderately or highly suitable habitat, with the most suitable habitat clustered around topographic highs along the Salas y Gómez and Nazca ridges, the waters around the Juan Fernández Islands, and the Foundation Seamount Chain. The patchy nature of the predicted distribution of all three species highlights the difficulties in achieving optimal spatial management with limited observation data, and reinforces the need for species distribution modeling to fill in key knowledge gaps. While the total area of highly suitable seafloor was predicted to be small, these patches extend over large distances, necessitating a regional conservation approach. It is also important to note that most large-scale features (e.g., seamounts, guyots, ridges, and escarpments) were predicted to be highly suitable for all three taxa, particularly within the Salas y Gómez and Nazca ridges. Surveys in the area have shown that seamounts along the ridges have unique assemblages, including species not found elsewhere along the ridges (Comité Oceanográfico Nacional de Chile 2017), further supporting the argument that protecting all of these features should be a high priority for conservation.

\section{Influence of Environmental Conditions}

Elevated and more complex seafloor topography has long been known to exert a strong influence on the success of many benthic species including corals and sponges (e.g., Rowden et al. 2017; Chu et al. 2019). As suspension and filter feeders, corals and sponges are heavily reliant on local and regional currents to increase food supply (Purser et al. 2010), transport larva (Piepenburg and Müller 2004), and prevent sedimentation of both tissues and benthic surfaces required for recruitment (Rogers 1994). Elevated and complex terrain affect current regimes in ways that can be favorable for the recruitment and success of cold-water corals and sponges (Masson et al. 2003; Bryan and Metaxas 2006). Accordingly, all three taxa in our study appeared to have a strong affinity for seamounts, guyots, ridges, and escarpments, with a clear preference for high TPI and VRM values (indicating locally elevated and complex surfaces).

It was surprising that stony corals appeared to prefer flatter surfaces, while both sponge groups preferred steeper slopes. The response of stony corals to slope may be explained by the low variable contribution of slope to the stony coral model, and the larger contribution of other terrain features. However, a closer examination of the habitat suitability predictions around large seafloor features showed that stony corals appeared to prefer the summits of seamounts and flattopped guyots to their steeper flanks, suggesting that this relationship may reflect a real preference for being on the tops, rather than the sides, of large terrain features. In contrast, highly suitable glass sponge habitats clustered preferentially on the steeper slopes of large features

Peerj reviewing PDF | (2021:02:58211:1:1:NEW 14 Jul 2021) 
518 while also showing a preference for steeper slopes. The flanks and summits of seamounts can 519 contain drastically different environmental conditions due to depth gradients, extreme

520 hydrological forces, exposure to oxygen-minimum zones, and the topography and sediment type

521 of the summit (Clark et al. 2010). Further observations on a finer scale than achieved here are

522 necessary to confirm and explain this pattern.

523 The waters surrounding the Salsas y Gómez and Nazca ridges are generally oligotrophic

524 (Von Dassow and Collado-Fabbri 2014; Gonzalez et al. 2019) and oxygen-poor (Espinoza-

525 Morribedon et al. 2019), suggesting that these variables could play large roles in determining

526

527 species distributions throughout the region. Nitrate and phosphate only contributed a low-

528 moderate amount of information to the models for each taxon, although response curves did indicate that both sponge taxa had an apparent preference for higher nitrate and lower phosphate

529

530

531

532

533

534

535

536

537

538

539

540

541

542

543

544

545

546

547

548

549

550

551

552

553

554

555

556 concentrations. However, research suggests that phosphate and nitrate uptake in sponges is negligible and unlikely to significantly limit distribution (Yahel et al. 2007; Perea-Blazquez et al. 2012).

Dissolved oxygen concentration is frequently suggested as being critically important for cold-water corals (Dodds et al. 2007; Lunden et al. 2014) and sponges (Whitney et al. 2005). However, it generally did not contribute considerable information to the models in this study, and only glass sponges demonstrated a notable increase in suitability in response to higher dissolved oxygen concentrations. For stony corals and demosponges, this may suggest that dissolved oxygen is not a limiting factor in the region, congruent with other work showing that cold-water coral communities can grow successfully even in very low oxygen conditions (e.g., approximately $2.5 \mathrm{ml} \mathrm{l}^{-1}$ at deep-water reefs in the Gulf of Mexico; Georgian et al. 2016).

Similarly, research suggests that some sponges can tolerate periods of hypoxia, although they do so at the expense of other metabolic functioning (Leys et al. 2018). In contrast, low dissolved oxygen concentrations have been suggested to be the primary limiting growth factor for glass sponge reefs in some regions (Leys et al. 2004), suggesting that dissolved oxygen may partially limit their distribution on the Salas y Gómez and Nazca ridges.

POC flux to the seafloor represents a proxy for food supply to benthic communities and is critically important for the success of deep-water corals and sponges (Wagner et al. 2011; Kahn et al. 2015). POC contributed significantly to the models for all taxa in this study, with suitability predicted to be highest at POC fluxes between approximately $5-50 \mathrm{~g} \mathrm{C} \mathrm{m}^{2}$. It was surprising that habitat suitability for each taxon actually decreased after POC fluxes of approximately $50 \mathrm{~g} \mathrm{C} \mathrm{m}^{2}$. However, correlations with other variables including depth, dissolved oxygen, temperature, $\Omega_{\mathrm{A}}$, and silicate may explain this trend. POC values greater than $50 \mathrm{~g} \mathrm{C} \mathrm{m}^{-2}$ were also spatially rare within the study region, with higher values almost exclusively occurring in shallower, coastal waters. In the offshore regions containing deep-water coral and sponge habitats, POC flux was extremely low (generally $<10 \mathrm{~g} \mathrm{C} \mathrm{m}^{-2}$ ), suggesting that these communities may be food limited by default. However, corals and sponges may also uptake dissolved organic carbon (DOC) (Weisz et al. 2008; Gori et al. 2014), or receive food from the 
557 lateral transport of POC (e.g., Rowe et al. 2008), potentially decoupling the relationship between

558

559

560

561

562

563

564

565

566

567

568

569

570

571

572

573

574

575

576

577

578

579

580

581

582

583

584

585

586

587

588

589

590

591

592

593

594

595

596

vertical POC flux to the seafloor and food supply.

Stony corals produce their hard skeletons using the aragonite form of calcium carbonate, with this mineral often serving as the foundation of entire deep-water ecosystems. The saturation state of aragonite $\left(\Omega_{\mathrm{A}}\right)$ represents the tendency for aragonite to form or dissolve in seawater, with values $>1$ indicating supersaturated waters where formation is thermodynamically favored. In our study, $\Omega_{\mathrm{A}}$ was the dominant contributing variable in each model type for stony corals, with response curves indicating a clear preference for supersaturated $\Omega_{\mathrm{A}}$ values above approximately 1.5. This conforms with numerous field surveys (Lunden et al. 2014; Georgian et al. 2016a), experimental results (Georgian et al. 2016b; Kurman et al. 2017), and modeling studies (e.g., Guinotte et al. 2006; Davies and Guinotte 2011) suggesting that aragonite supersaturation is a primary requirement for the growth and success of deep-water stony corals. While survival is still possible in undersaturated waters (Thresher et al. 2011), there are large energetic costs associated with calcifying under these conditions (McCulloch et al. 2012; Wall et al. 2015), which generally require additional resources via increased feeding rates (Georgian et al. 2016b).

While silicate was important in both sponge models, it was surprising that demosponge and glass sponge suitability was lower in areas with higher silicate concentrations, as both taxa produce extensive silicate skeletal materials (as much as $80 \%$ of the dry weight of glass sponges can be made up of silicate; Chu et al. 2011). Previous work has found clear links between sponge distributions and silicate concentrations (e.g., Whitney et al. 2005; Howell et al. 2016), with silicate uptake becoming more energetically costly when environmental concentrations are low (Krasko et al. 2000). However, extensive glass sponge reefs have been documented at similar

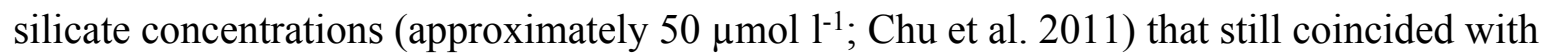
predicted high suitability in our study, with response curves indicating a steep decline in suitability in concentrations starting only around $30 \mu \mathrm{mol} \mathrm{l}^{-1}$. This suggests that it is possible that once a minimum concentration of silicate is reached, there is little additional biological benefit to growing in higher concentrations, allowing the relative importance of other variables to become more important. This finding aligns well with previous suggesting that a lower silicate level of approximately $30-40 \mu \mathrm{mol} \mathrm{l}^{-1}$ may be the lower limit for optimal sponge growth (Leys et al. 2004).

It is also possible that the lower native resolutions of the nutrient, POC, aragonite saturation state, and dissolved oxygen datasets (see Table 1) precluded a more important role in the models, as well as potentially complicating their ecological interpretability. In addition, as comparisons of interpolated layers were not perfectly correlated with water-controlled bottle data from GLODAP (Supplemental Figure 23), it is likely that the environmental layers used in our study contain small errors, or that these data are temporally variable. These potential sources of error may complicate the ecological interpretation of these variables, especially when variables are already moderately to highly correlated with other variables (whether included or excluded in final models; see Supplemental Table 1). However, bean plots and response curves generally demonstrated a strong habitat preference for most key variables, suggesting that these variables

Peer] reviewing PDF | (2021:02:58211:1:1:NEW 14 Jul 2021) 
597 are more important on regional scales where the effects of small errors should be negligible.

598 Future work should be completed to improve variable resolution and validate these data in order

599 to more accurately assess how these environmental conditions affect the distribution and niche of

600 these taxa throughout the region. Improved datasets would also considerably improve our ability

601 to predict and map the potential shift in suitable habitat under future scenarios expected with

602 ongoing warming, ocean acidification, shifts in primary productivity, and deoxygenation.

603

604 Threats

605 Anthropogenic impacts to deep-sea environments are increasing at an unprecedented rate

606 and scale (reviewed in Ramirez-Llodra et al. 2011). Despite their remote offshore location, the

607 Salas y Gómez and Nazca ridges are not immune to the risks posed by human activities,

608 including commercial fishing, pollution, climate change, and potential seabed mining (reviewed

609 by Wagner et al. 2021). Bottom fisheries are frequently cited as one of the most damaging

610 activities for deep-water coral and sponge habitats (Watling and Norse 1998; Pusceddu et al.

611 2014), given the indiscriminate and destructive nature of the trawls, lines, and other equipment

612 used. Suitable habitat for corals and sponges often overlaps with bottom fisheries due to the

613 strong association of many demersal fish species with seamounts and similar features, as well as

614 with the habitat structures created by corals and sponges themselves (Baillon et al. 2012; Kutti et

615 al. 2014). The Salas y Gómez and Nazca ridges have been sporadically but not heavily trawled in

616 the past, with a bottom trawl closure for orange roughy enacted by SPRFMO in 2006 (reviewed

617 in Tingley and Dunn 2018). Long-lining and pelagic fisheries do target the ridges, but for most

618 target species, fishing effort in the region has been historically low (Wagner et al. 2021).

619 Therefore, this area presents a unique opportunity to implement strong protections before

620 widespread and irrevocable damage occurs.

621 Like every major marine habitat studied, the Salas y Gómez and Nazca ridges are

622 affected by marine debris pollution including abandoned fishing gear and plastics, with the bulk

623 of materials stemming from high seas fisheries in the South Pacific (Luna-Jorquera et al. 2019)

624 or coastal regions via the confluence of the Humboldt Current System and the South Pacific

625 Subtropical Gyre (Thiel et al. 2018). Plastic pollution alone is estimated to affect more than 97

626 species in the region through entanglement and ingestion, including fish, sea turtles, seabirds,

627 and marine mammals. While the harmful effects of marine debris are better documented in

628 pelagic species, microplastics have been found to significantly reduce the growth and feeding of

629 deep-water corals, and derelict fishing gear causes physical damage to deep-water reefs and

630 harms mobile fauna via ghost fishing (Chapron et al. 2018; La Beur et al. 2019).

631 Seabed mining is a new but imminent threat to many deep-sea environments including

632 the Salas y Gómez and Nazca ridges. Deposits of cobalt, manganese, and polymetallic massive

633 sulfides are known to exist on or near the ridges (Hein et al. 2013; Miller et al. 2018; García et

634 al. 2020), leaving this area susceptible to future mining interests. While seabed mineral

635 extraction has not yet occurred, rising demand for minerals coupled with technological advances

636 in mining equipment are rapidly increasing global interest in the mining industry. If allowed to 
637 occur, seabed mining will cause widespread and serious harm to sensitive benthic habitats via the 638 physical disruption of the seafloor and sedimentation of neighboring habitats (Van Dover et al. 639 2017).

640 One of the largest threats to most marine habitats is anthropogenic emissions, which are 641 driving unprecedented rates of warming, deoxygenation, acidification, and decreased

642 productivity in deep-sea environments (Mora et al. 2013). For coral and sponge habitats along

643 the Salas y Gómez and Nazca ridges that already experience average or seasonally low dissolved

644 oxygen, low $\Omega_{\mathrm{A}}$, high temperatures, or low POC flux, climate change may rapidly render even

645 highly suitable habitats unviable for the long-term survival of these taxa. If the rate of

646 environmental change is faster than species can adapt or acclimate, the distribution of many

647 fauna may be considerably reduced, potentially resulting in widespread ecosystem collapse (e.g.,

648 Ullah et al. 2018). Climate change will also exacerbate local stressors including fishing and

649 pollution, reducing both the resiliency of ecosystems as well as their ability to recover from

650 disturbances. However, marine protected areas are increasingly viewed as a viable tool to

651 mitigate the results of climate change (Mumby et al. 2010; Micheli et al. 2012; Roberts et al.

652 2017).

653

654

$\underline{\text { Implications for High Seas Conservation and Management }}$

655

656

ABNJ, commonly known as the high seas, cover more than $61 \%$ of the global ocean

657 surface and $73 \%$ of its volume. These remote ocean areas are not only vast, but also critical for

658 sustaining life on Earth, as they contain nearly $90 \%$ of the total ocean biomass, produce nearly

659 half of the oxygen, and capture over 1.5 billion tons of carbon dioxide each year (Van den Hove

660 and Moreau 2007; Global Ocean Commission 2014; Laffoley et al. 2014). Yet only 1.3\% of

661 ABNJ are currently protected within marine protected areas (MPAtlas 2021), despite widespread and rapidly increasing threats. The lack of high seas protections is in large part due to the

662 makeshift legal framework that is currently in place to protect ABNJ (Molenaar and Elferink 2009; Gjerde et al. 2016), as well as the lack of awareness that important ecosystems exist within these remote ocean areas. The results of this study indicate that deep-sea corals and sponges, which build the foundation for some of the most abundant and diverse communities in the deep sea (Rogers 1999; Costello et al. 2005; Kenchington et al. 2013), are widespread on seamounts and ridges located in high seas waters of the South Pacific. Given the ecological importance of deep-sea corals and sponges, and their high vulnerability to human impacts, areas that host these

669 communities should be protected from exploitation using the best available conservation

670 measures. Regional fishery management organizations that manage fisheries in this region,

671 namely SPRFMO and IATTC, as well as the ISA which manages seabed mining in international

672 waters globally, already have established mechanisms to protect sensitive marine habitats.

673 Commercial fishing in this region has been very limited in recent years, and deep-sea mineral

674 exploration has not occurred (Wagner et al. 2021), providing a time-sensitive opportunity to 675 protect this region without significantly impacting those industries. We thus urge member States 
676 of SPRFMO, IATTC, and ISA to close this region to fishing and mining activities before it is too 677 late.

678

679 Conclusions

680

681

682

The scarcity of data concerning the distribution of key habitat-forming fauna represents an obstacle to conservation efforts. We found that highly suitable habitat for demosponges, glass

683 sponges, and stony corals likely occurs throughout the study area, particularly on large terrain

684 features including seamounts, guyots, ridges, and escarpments of the Salas y Gómez and Nazca

685 ridges. When previously visited during the limited expeditions to the area, these taxa were found to support abundant and diverse ecosystems housing a wide array of associated species (e.g.,

686 Comité Oceanográfico Nacional de Chile 2017). It is our hope that these models will inform

687 expedition planning and future research, improve our understanding of the niche and distribution

688 of key taxa, and be considered in a science-based spatial management plan for the region.

689 Anthropogenic disturbance in the deep sea is increasing at an alarming rate, making it imperative

690 to enact strong, permanent protection before these communities are irrevocably damaged.

691

692

693

694

695

696

697

698

699

700

701

702

703

704

705

706

707

708

709

710

711

712

713

714

715

716

717

\section{Acknowledgements}

We are grateful for species occurrence records provided by Javier Sellanes (Universidad Católica del Norte) and Erin Easton (The University of Texas Rio Grande Valley). In addition, we are grateful to the NOAA Deep-sea Coral Data Portal and the Ocean Biodiversity Information System for their continued efforts to collect and publish taxonomic records, as well as to all of the researchers who have shared their data through these programs.

\section{References}

Allouche, O., Tsoar, A., \& Kadmon, R. (2006). Assessing the accuracy of species distribution models: prevalence, kappa and the true skill statistic (TSS). Journal of applied ecology, 43(6), 1223-1232.

Andrade, I., Hormazábal, S., \& Correa-Ramírez, M. (2014). Time-space variability of satellite chlorophyll-a in the Easter Island Province, southeastern Pacific Ocean. Latin American Journal of Aquatic Research, 42(4), 871-887.

Aqua MODIS. (2018). NASA Goddard Space Flight Center, Ocean Ecology Laboratory, Ocean Biology Processing Group. 2018. Moderate-resolution Imaging Spectroradiometer (MODIS) Aqua Chlorophyll and Sea Surface Temperature Data; 2018 Reprocessing. NASA OB.DAAC, Greenbelt, MD, USA.

Baco, A. R., Roark, E. B., \& Morgan, N. B. (2019). Amid fields of rubble, scars, and lost gear, signs of recovery observed on seamounts on 30-to 40-year time scales. Science advances, 5(8), eaaw4513.

Baillon, S., Hamel, J. F., Wareham, V. E., \& Mercier, A. (2012). Deep cold-water corals as nurseries for fish larvae. Frontiers in Ecology and the Environment, 10(7), 351-356.

Becker, J. J., Sandwell, D. T., Smith, W. H. F., Braud, J., Binder, B., Depner, J. L., ... \& Weatherall, P. (2009). Global bathymetry and elevation data at 30 arc seconds resolution: SRTM30_PLUS. Marine Geodesy, 32(4), 355-371. 
718 Breiman, L. (2001). Random forests. Machine learning, 45(1), 5-32.

719 Bryan, T. L., \& Metaxas, A. (2006). Distribution of deep-water corals along the North American

720

721

722

723

724

725

726

727

728

729

730

731

732

733

734

735

736

737

738

739

740

741

742

743

744

745

746

747

748

749

750

751

752

753

754

755

756

757

758

759

760

761

762

763 continental margins: relationships with environmental factors. Deep Sea Research Part I: Oceanographic Research Papers, 53(12), 1865-1879.

Cao, L., Fairbanks, R. G., Mortlock, R. A., \& Risk, M. J. (2007). Radiocarbon reservoir age of high latitude North Atlantic surface water during the last deglacial. Quaternary Science Reviews, 26(5-6), 732-742.

Carton, J. A., \& Giese, B. S. (2008). A reanalysis of ocean climate using Simple Ocean Data Assimilation (SODA). Monthly weather review, 136(8), 2999-3017.

CBD (2014). Decision adopted by the Conference of the Parties to the Convention on Biological Diversity. Conference of the Parties to the Convention on Biological Diversity Twelfth Meeting. Pyeongchang, Republic of Korea, 6-17 October 2014. Agenda item 21. 59 pp. CBD (2017). Ecologically or Biologically Significant Areas (EBSAs) - Dorsal de Nazca y de Salas y Gómez (Salas y Gómez and Nazca Ridges). 8 pp.

Chapron, L., Peru, E., Engler, A., Ghiglione, J. F., Meistertzheim, A. L., Pruski, A. M., ... \& Lartaud, F. (2018). Macro-and microplastics affect cold-water corals growth, feeding and behaviour. Scientific reports, 8(1), 1-8.

Chu, J. W., Maldonado, M., Yahel, G., \& Leys, S. P. (2011). Glass sponge reefs as a silicon sink. Marine Ecology Progress Series, 441, 1-14.

Chu, J. W., Nephin, J., Georgian, S., Knudby, A., Rooper, C., \& Gale, K. S. (2019). Modelling the environmental niche space and distributions of cold-water corals and sponges in the Canadian northeast Pacific Ocean. Deep Sea Research Part I: Oceanographic Research Papers, 151, 103063.

Clark, M. R., Rowden, A. A., Schlacher, T., Williams, A., Consalvey, M., Stocks, K. I., ... \& Hall-Spencer, J. M. (2010). The ecology of seamounts: structure, function, and human impacts. Annual Review of Marine Science, 2, 253-278.

Comité Oceanográfico Nacional de Chile (2017). Crucero CIMAR 22 Islas Oceánicas (13 de octubre al 14 de noviembre de 2016) resultados preliminares. $130 \mathrm{pp}$.

Cordes EE, McGinley MP, Podowski EL, Becker EL, Lessard-Pilon S, Viada ST, Fisher CR. Coral communities of the deep Gulf of Mexico. Deep Sea Research Part I: Oceanographic Research Papers. 2008 Jun 1;55(6):777-87.

Costello, M. J., McCrea, M., Freiwald, A., Lundälv, T., Jonsson, L., Bett, B. J., ... \& Allen, D. (2005). Role of cold-water Lophelia pertusa coral reefs as fish habitat in the NE Atlantic. In Cold-water corals and ecosystems (pp. 771-805). Springer, Berlin, Heidelberg.

Davies, A. J., \& Guinotte, J. M. (2011). Global habitat suitability for framework-forming coldwater corals. PloS one, 6(4), e18483.

Diaz-Diaz, O. F., Rozbaczylo, N., Sellanes, J., \& Tapia-Guerra, J. M. (2020). A new species of Eunice Cuvier, 1817 (Polychaeta: Eunicidae) from the slope of the Desventuradas Islands and seamounts of the Nazca Ridge, southeastern Pacific Ocean. Zootaxa, 4860(2), zootaxa4860 .

Dodds, L. A., Roberts, J. M., Taylor, A. C., \& Marubini, F. (2007). Metabolic tolerance of the cold-water coral Lophelia pertusa (Scleractinia) to temperature and dissolved oxygen change. Journal of Experimental Marine Biology and Ecology, 349(2), 205-214.

Dorschel, B., Hebbeln, D., Foubert, A., White, M., \& Wheeler, A. J. (2007). Cold-water coral carbonate mound hydrodynamics and facies distributions: instrumentation and model development. Marine Geology, 244(1-4), 184-195.

PeerJ reviewing PDF | (2021:02:58211:1:1:NEW 14 Jul 2021) 
764

765

766

767

768

769

770

771

772

773

774

775

776

777

778

779

780

781

782

783

784

785

786

787

788

789

790

791

792

793

794

795

796

797

798

799

800

801

802

803

804

805

806

807

808
Doughty, C. L., Quattrini, A. M., \& Cordes, E. E. (2014). Insights into the population dynamics of the deep-sea coral genus Paramuricea in the Gulf of Mexico. Deep Sea Research Part II: Topical Studies in Oceanography, 99, 71-82.

Duroux R, Scornet E. Impact of subsampling and tree depth on random forests. ESAIM: Probability and Statistics. 2018;22:96-128.

Easton, E. E., Gorny, M., Mecho, A., Sellanes, J., Gaymer, C. F., Spalding, H. L., \& Aburto, J. (2019). Chile and the Salas y Gómez ridge. In Mesophotic Coral Ecosystems (pp. 477-490). Springer, Cham.

Elith, J., H. Graham, C., P. Anderson, R., Dudík, M., Ferrier, S., Guisan, A., ... \& E. Zimmermann, N. (2006). Novel methods improve prediction of species' distributions from occurrence data. Ecography, 29(2), 129-151.

Elith, J., Kearney, M., \& Phillips, S. (2010). The art of modelling range-shifting species. Methods in ecology and evolution, 1(4), 330-342.

Elith, J., Leathwick, J. R., \& Hastie, T. (2008). A working guide to boosted regression trees. Journal of Animal Ecology, 77(4), 802-813.

Espinoza-Morriberón, D., Echevin, V., Colas, F., Tam, J., Gutierrez, D., Graco, M., ... \& QuispeCcalluari, C. (2019). Oxygen variability during ENSO in the tropical South Eastern Pacific. Frontiers in Marine Science, 5, 526.

Fallon, S. J., James, K., Norman, R., Kelly, M., \& Ellwood, M. J. (2010). A simple radiocarbon dating method for determining the age and growth rate of deep-sea sponges. Nuclear Instruments and Methods in Physics Research Section B: Beam Interactions with Materials and Atoms, 268(7-8), 1241-1243.

FAO. (2009). International guidelines for the management of deep-sea fisheries in the high seas. Food and Agriculture Organization.

Fitzpatrick, M. C., Gotelli, N. J., \& Ellison, A. M. (2013). MaxEnt versus MaxLike: empirical comparisons with ant species distributions. Ecosphere, 4(5), 1-15.

Friedlander, A. M., Goodell, W., Giddens, J., Easton, E. E. \& Wagner, D. (in press). Deep-sea biodiversity at the extremes of the Salas y Gómez and Nazca ridges with implications for conservation. Plos One.

Friedlander, A. M., Ballesteros, E., Caselle, J. E., Gaymer, C. F., Palma, A. T., Petit, I., ... \& Sala, E. (2016). Marine biodiversity in Juan Fernández and Desventuradas Islands, Chile: global endemism hotspots. PLoS One, 11(1), e0145059.

Fujioka, E., \& Halpin, P. N. (2014). Spatio-temporal assessments of biodiversity in the high seas. Endangered Species Research, 24(2), 181-190.

Garcia, H. E., Boyer, T. P., Locarnini, R. A., Antonov, J. I., Mishonov, A. V., Baranova, O. K., ... \& Levitus, S. (2013a). World ocean atlas 2013. Volume 3, Dissolved oxygen, apparent oxygen utilization, and oxygen saturation.

Garcia, H. E., Locarnini, R. A., Boyer, T. P., Antonov, J. I., Baranova, O. K., Zweng, M. M., ... \& Levitus, S. (2013b). World ocean atlas 2013. Volume 4, Dissolved inorganic nutrients (phosphate, nitrate, silicate).

García, M., Correa Drubi, J., Maksaev, V., \& Townley Callejas, B. (2020). Potential mineral resources of the Chilean offshore: an overview.

Georgian, S. E., Anderson, O. F., \& Rowden, A. A. (2019). Ensemble habitat suitability modeling of vulnerable marine ecosystem indicator taxa to inform deep-sea fisheries management in the South Pacific Ocean. Fisheries Research, 211, 256-274. 
809 Georgian, S. E., DeLeo, D., Durkin, A., Gomez, C. E., Kurman, M., Lunden, J. J., \& Cordes, E.

810

811

812

813

814

815

816

817

818

819

820

821

822

823

824

825

826

827

828

829

830

831

832

833

834

835

836

837

838

839

840

841

842

843

844

845

846

847

848

849

850

851

852

853

854 E. (2016a). Oceanographic patterns and carbonate chemistry in the vicinity of cold-water coral reefs in the Gulf of Mexico: Implications for resilience in a changing ocean. Limnology and Oceanography, 61(2), 648-665.

Georgian, S. E., Dupont, S., Kurman, M., Butler, A., Strömberg, S. M., Larsson, A. I., \& Cordes, E. E. (2016b). Biogeographic variability in the physiological response of the cold-water coral Lophelia pertusa to ocean acidification. Marine Ecology, 37(6), 1345-1359.

Georgian, S. E., Kramer, K., Saunders, M., Shedd, W., Roberts, H., Lewis, C., ... \& Cordes, E. (2020). Habitat suitability modelling to predict the spatial distribution of cold-water coral communities affected by the Deepwater Horizon oil spill. Journal of Biogeography, 47(7), 1455-1466.

Georgian, S. E., Shedd, W., \& Cordes, E. E. (2014). High-resolution ecological niche modelling of the cold-water coral Lophelia pertusa in the Gulf of Mexico. Marine Ecology Progress Series, 506, 145-161.

Gjerde, K. M., Wright, G., Durussel, C., Gjerde, K. M., \& Wright, G. (2021). Strengthening high seas governance through enhanced environmental assessment processes: A case study of mesopelagic fisheries and options for a future BBNJ treaty. STRONG High Seas Project.

Gjerde, K., Reeve, L., Harden-Davies, H., Ardron, J., Dolan, R., Durussel, C., ... \& Wright, G. (2016). Protecting Earth's last conservation frontier: scientific, management and legal priorities for MPAs beyond national boundaries.

Global Ocean Commission. (2014). From decline to recovery: A rescue package for the global ocean. Global Ocean Commission.

González, C. E., Escribano, R., Bode, A., \& Schneider, W. (2019). Zooplankton taxonomic and trophic community structure across biogeochemical regions in the eastern South Pacific. Frontiers in Marine Science, 5, 498.

Gori, A., Grover, R., Orejas, C., Sikorski, S., \& Ferrier-Pagès, C. (2014). Uptake of dissolved free amino acids by four cold-water coral species from the Mediterranean Sea. Deep Sea Research Part II: Topical Studies in Oceanography, 99, 42-50.

Guinotte, J. M., Orr, J., Cairns, S., Freiwald, A., Morgan, L., \& George, R. (2006). Will human-induced changes in seawater chemistry alter the distribution of deep-sea scleractinian corals?. Frontiers in Ecology and the Environment, 4(3), 141-146.

Guisan, A., \& Zimmermann, N. E. (2000). Predictive habitat distribution models in ecology. Ecological modelling, 135(2-3), 147-186.

Harris, P. T., Macmillan-Lawler, M., Rupp, J., \& Baker, E. K. (2014). Geomorphology of the oceans. Marine Geology, 352, 4-24.

Hastle, T. J., \& Tibshirani, R. (1986). Generalized additive models (with discussion). Statist. Sci, 1, 336-337.

Hein, J. R., Mizell, K., Koschinsky, A., \& Conrad, T. A. (2013). Deep-ocean mineral deposits as a source of critical metals for high-and green-technology applications: Comparison with land-based resources. Ore Geology Reviews, 51, 1-14.

Hijmans, R. J., Phillips, S., Leathwick, J., Elith, J., \& Hijmans, M. R. J. (2017). Package ‘dismo’. Circles, 9(1), 1-68.

Hill, R. T. (2003). Microbes from marine sponges: a treasure trove of biodiversity for natural products discovery. Microbial diversity and bioprospecting, 177-190.

Hirzel, A. H., Hausser, J., Chessel, D., \& Perrin, N. (2002). Ecological-niche factor analysis: how to compute habitat-suitability maps without absence data?. Ecology, 83(7), 2027-2036.

Peer] reviewing PDF | (2021:02:58211:1:1:NEW 14 Jul 2021) 
855

856

857

858

859

860

861

862

863

864

865

866

867

868

869

870

871

872

873

874

875

876

877

878

879

880

881

882

883

884

885

886

887

888

889

890

891

892

893

894

895

896

897

898

899

900

Hobson, R. D. (1972). Surface Roughness in Topography: A Quantitative Approach. In Chorley, R.J., Ed., Spatial Analysis in Geomorphology, Methuen \& Co., London, 221-245.

Howell, K. L., Piechaud, N., Downie, A. L., \& Kenny, A. (2016). The distribution of deep-sea sponge aggregations in the North Atlantic and implications for their effective spatial management. Deep Sea Research Part I: Oceanographic Research Papers, 115, 309-320.

Huang, Z., Brooke, B., \& Li, J. (2011). Performance of predictive models in marine benthic environments based on predictions of sponge distribution on the Australian continental shelf. Ecological Informatics, 6(3-4), 205-216.

Hubbard, D. K., \& Garcia, M. (2003). The corals and coral reefs of Easter Island - a preliminary look. In Easter Island (pp. 53-77). Springer, Boston, MA.

Hucke-Gaete, R., Aguayo-Lobo, A., Yancovic-Pakarati, S., \& Flores, M. (2014). Marine mammals of Easter Island (Rapa Nui) and Salas y Gómez Island (Motu Motiro Hiva), Chile: a review and new records. Latin American Journal of Aquatic Research, 42, 743-751.

Iturbide, M., Bedia, J., Herrera, S., del Hierro, O., Pinto, M., and Gutiérrez, J. M. 2015. A framework for species distribution modelling with improved pseudo-absence generation. Ecological Modelling, 312, 166-174. https ://doi.org/10.1016/j.ecolm odel.2015.05.018 Jenness, J. (2013a). DEM surface tools. Jenness Enterprises.

Jenness, J. S. (2004). Calculating landscape surface area from digital elevation models. Wildlife Society Bulletin, 32(3), 829-839.

Jenness, J., Brost, B., \& Beier, P. (2013b). Land facet corridor designer. USDA forest service rocky mountain research station.

Jones, K. H. (1998). A comparison of algorithms used to compute hill slope as a property of the DEM. Computers \& Geosciences, 24(4), 315-323.

Kahn, A. S., Yahel, G., Chu, J. W., Tunnicliffe, V., \& Leys, S. P. (2015). Benthic grazing and carbon sequestration by deep-water glass sponge reefs. Limnology and Oceanography, 60(1), 78-88.

Kenchington, E., Power, D., \& Koen-Alonso, M. (2013). Associations of demersal fish with sponge grounds on the continental slopes of the northwest Atlantic. Marine Ecology Progress Series, 477, 217-230.

Knudby, A., Kenchington, E., \& Murillo, F. J. (2013). Modeling the distribution of Geodia sponges and sponge grounds in the Northwest Atlantic. PloS one, 8(12), e82306.

Kramer-Schadt, S., Niedballa, J., Pilgrim, J. D., Schröder, B., Lindenborn, J., Reinfelder, V., ... \& Wilting, A. (2013). The importance of correcting for sampling bias in MaxEnt species distribution models. Diversity and Distributions, 19(11), 1366-1379.

Krasko, A., Lorenz, B., Batel, R., Schröder, H. C., Müller, I. M., \& Müller, W. E. (2000). Expression of silicatein and collagen genes in the marine sponge Suberites domuncula is controlled by silicate and myotrophin. European Journal of Biochemistry, 267(15), 48784887.

Kurman, M. D., Gomez, C. E., Georgian, S. E., Lunden, J. J., \& Cordes, E. E. (2017). Intraspecific variation reveals potential for adaptation to ocean acidification in a cold-water coral from the Gulf of Mexico. Frontiers in Marine Science, 4, 111.

Kutti, T., Bergstad, O. A., Fosså, J. H., \& Helle, K. (2014). Cold-water coral mounds and sponge-beds as habitats for demersal fish on the Norwegian shelf. Deep Sea Research Part II: Topical Studies in Oceanography, 99, 122-133.

La Beur, L., Henry, L. A., Kazanidis, G., Hennige, S., McDonald, A., Shaver, M. P., \& Roberts, J. M. (2019). Baseline assessment of marine litter and microplastic ingestion by cold-water

Peer) reviewing PDF | (2021:02:58211:1:1:NEW 14 Jul 2021) 
905

906

907

908

909

910

911

912

913

914

915

916

917

918

919

920

921

922

923

924

925

926

927

928

929

930

931

932

933

934

935

936

937

938

939

940

941

942

943

944

945

coral reef benthos at the East Mingulay Marine Protected Area (Sea of the Hebrides, western Scotland). Frontiers in Marine Science, 6, 80.

Laffoley, D., Baxter, J. M., \& Thevenon, F., \& Oliver, J. (2014). The Significance and Management of Natural Carbon Stores in the Open Ocean. IUCN Global Marine and Polar Programme.

Leys, S. P., \& Kahn, A. S. (2018). Oxygen and the energetic requirements of the first multicellular animals. Integrative and comparative biology, 58(4), 666-676.

Leys, S. P., Wilson, K., Holeton, C., Reiswig, H. M., Austin, W. C., \& Tunnicliffe, V. (2004). Patterns of glass sponge (Porifera, Hexactinellida) distribution in coastal waters of British Columbia, Canada. Marine Ecology Progress Series, 283, 133-149.

Liaw, A., \& Wiener, M. (2002). Classification and regression by randomForest. R news, 2(3), $18-22$.

Locarnini, R. A. (2013). World Ocean Atlas 2013, Volume 1: Temperature. S. Levitus, Ed.; A. Mishonov, Technical Ed.; NOAA Atlas NESDIS 73, 40 pp.

Luna-Jorquera, G., Thiel, M., Portflitt-Toro, M., \& Dewitte, B. (2019). Marine protected areas invaded by floating anthropogenic litter: An example from the South Pacific. Aquatic Conservation: Marine and Freshwater Ecosystems, 29, 245-259.

Lunden, J. J., McNicholl, C. G., Sears, C. R., Morrison, C. L., \& Cordes, E. E. (2014). Acute survivorship of the deep-sea coral Lophelia pertusa from the Gulf of Mexico under acidification, warming, and deoxygenation. Frontiers in Marine Science, 1, 78.

Lutz, M. J., Caldeira, K., Dunbar, R. B., \& Behrenfeld, M. J. (2007). Seasonal rhythms of net primary production and particulate organic carbon flux to depth describe the efficiency of biological pump in the global ocean. Journal of Geophysical Research: Oceans, 112(C10).

Marine Conservation Institute. (2021). MPAtlas. Seattle, WA. www.mpatlas.org [Accessed 02/18/2021].

Masson, D. G., Bett, B. J., Billett, D. S. M., Jacobs, C. L., Wheeler, A. J., \& Wynn, R. B. (2003). The origin of deep-water, coral-topped mounds in the northern Rockall Trough, Northeast Atlantic. Marine Geology, 194(3-4), 159-180.

McCulloch, M., Trotter, J., Montagna, P., Falter, J., Dunbar, R., Freiwald, A., ... \& Taviani, M. (2012). Resilience of cold-water scleractinian corals to ocean acidification: Boron isotopic systematics of $\mathrm{pH}$ and saturation state up-regulation. Geochimica et Cosmochimica Acta, 87, 21-34.

Micheli, F., Saenz-Arroyo, A., Greenley, A., Vazquez, L., Montes, J. A. E., Rossetto, M., \& De Leo, G. A. (2012). Evidence that marine reserves enhance resilience to climatic impacts. PloS one, 7(7), e40832.

Mienis, F., De Stigter, H. C., De Haas, H., \& Van Weering, T. C. E. (2009). Near-bed particle deposition and resuspension in a cold-water coral mound area at the Southwest Rockall Trough margin, NE Atlantic. Deep Sea Research Part I: Oceanographic Research Papers, 56(6), 1026-1038.

Miller, J. (2010). Species distribution modeling. Geography Compass, 4(6), 490-509.

Miller, K. A., Thompson, K. F., Johnston, P., \& Santillo, D. (2018). An overview of seabed mining including the current state of development, environmental impacts, and knowledge gaps. Frontiers in Marine Science, 4, 418.

Molenaar, E. J., \& Elferink, A. G. O. (2009). Marine protected areas in areas beyond national jurisdiction-the pioneering efforts under the OSPAR convention. Utrecht L. Rev., 5, 5. 
946 Mora, C., Wei, C. L., Rollo, A., Amaro, T., Baco, A. R., Billett, D., ... \& Yasuhara, M. (2013).

947 Biotic and human vulnerability to projected changes in ocean biogeochemistry over the 21 st 948 century. PLoS Biol, 11(10), e1001682.

949 Müller, W. E., Schröder, H. C., Wiens, M., Perovic-Ottstadt, S., Batel, R., \& Müller, I. M.

950

951

952

953

954

955

956

957

958

959

960

961

962

963

964

965

966

967

968

969

970

971

972

973

974

975

976

977

978

979

980

981

982

983

984

985

986

987

988

989

990

991 (2004). Traditional and modern biomedical prospecting: Part II-the benefits. EvidenceBased Complementary and Alternative Medicine, 1(2), 133-144.

Mumby, P. J., \& Harborne, A. R. (2010). Marine reserves enhance the recovery of corals on Caribbean reefs. Plos one, 5(1), e8657.

Nadi A, Moradi H. Increasing the views and reducing the depth in random forest. Expert Systems with Applications. 2019 Dec 30;138:112801.

NOAA. (2020). NOAA National Database for Deep-Sea Corals and Sponges. https://deepseacoraldata.noaa.gov/; NOAA Deep Sea Coral Research \& Technology Program. Accessed 10/2020.

OBIS. (2020). Ocean Biodiversity Information System. Intergovernmental Oceanographic Commission of UNESCO. www.obis.org. Accessed 10/2020.

Oevelen, D. V., Duineveld, G., Lavaleye, M., Mienis, F., Soetaert, K., \& Heip, C. H. (2009). The cold-water coral community as hotspot of carbon cycling on continental margins: A food-web analysis from Rockall Bank (northeast Atlantic). Limnology and Oceanography, 54(6), 1829-1844.

Ortuño Crespo, G. O., Dunn, D. C., Gianni, M., Gjerde, K., Wright, G., \& Halpin, P. N. (2019). High-seas fish biodiversity is slipping through the governance net. Nature ecology \& evolution, 3(9), 1273-1276.

Parin, N. V. (1991). Fish fauna of the Nazca and Sala y Gomez submarine ridges, the easternmost outpost of the Indo-West Pacific zoogeographic region. Bulletin of Marine Science, 49(3), 671-683.

Parin, N. V., Mironov, A. N., \& Nesis, K. N. (1997). Biology of the Nazca and Sala y Gomez submarine ridges, an outpost of the Indo-West Pacific fauna in the eastern Pacific Ocean: composition and distribution of the fauna, its communities and history. Advances in Marine Biology, 32, 145-242.

Parker, S. J., Penney, A. J., \& Clark, M. R. (2009). Detection criteria for managing trawl impacts on vulnerable marine ecosystems in high seas fisheries of the South Pacific Ocean. Marine Ecology Progress Series, 397, 309-317.

Penney, A. J., Parker, S. J., \& Brown, J. H. (2009). Protection measures implemented by New Zealand for vulnerable marine ecosystems in the South Pacific Ocean. Marine Ecology Progress Series, 397, 341-354.

Perea-Blazquez, A., Davy, S. K., \& Bell, J. J. (2012). Estimates of particulate organic carbon flowing from the pelagic environment to the benthos through sponge assemblages. PloS one, 7(1), e29569.

Phillips, S. J., Anderson, R. P., \& Schapire, R. E. (2006). Maximum entropy modeling of species geographic distributions. Ecological modelling, 190(3-4), 231-259.

Piepenburg, D., \& Müller, B. (2004). Distribution of epibenthic communities on the Great Meteor Seamount (North-east Atlantic) mirrors pelagic processes. Archive of Fishery and Marine Research, 51(1-3), 55-70.

Prouty, N. G., Roark, E. B., Buster, N. A., \& Ross, S. W. (2011). Growth rate and age distribution of deep-sea black corals in the Gulf of Mexico. Marine Ecology Progress Series, $423,101-115$. 
992

993

994

995

996

997

998

999

1000

1001

1002

1003

1004

1005

1006

1007

1008

1009

1010

1011

1012

1013

1014

1015

1016

1017

1018

1019

1020

1021

1022

1023

1024

1025

1026

1027

1028

1029

1030

1031

1032

1033

1034

1035
Purser, A., Larsson, A. I., Thomsen, L., \& van Oevelen, D. (2010). The influence of flow velocity and food concentration on Lophelia pertusa (Scleractinia) zooplankton capture rates. Journal of Experimental Marine Biology and Ecology, 395(1-2), 55-62.

Pusceddu, A., Bianchelli, S., Martín, J., Puig, P., Palanques, A., Masqué, P., \& Danovaro, R. (2014). Chronic and intensive bottom trawling impairs deep-sea biodiversity and ecosystem functioning. Proceedings of the National Academy of Sciences, 111(24), 8861-8866.

R Core Team. (2019). R: A language and environment for statistical computing. R Foundation for Statistical Computing, Vienna, Austria. URL https://www.R-project.org/.

Ramirez-Llodra, E., Tyler, P. A., Baker, M. C., Bergstad, O. A., Clark, M. R., Escobar, E., ... \& Van Dover, C. L. (2011). Man and the last great wilderness: human impact on the deep sea. PLoS one, 6(8), e22588.

Ridgeway, G. (2004). The gbm package. R Foundation for Statistical Computing, Vienna, Austria.

Roark, E. B., Guilderson, T. P., Dunbar, R. B., Fallon, S. J., \& Mucciarone, D. A. (2009). Extreme longevity in proteinaceous deep-sea corals. Proceedings of the National Academy of Sciences, 106(13), 5204-5208.

Robert, K., Jones, D. O., Roberts, J. M., \& Huvenne, V. A. (2016). Improving predictive mapping of deep-water habitats: Considering multiple model outputs and ensemble techniques. Deep Sea Research Part I: Oceanographic Research Papers, 113, 80-89.

Roberts, C. M., O’Leary, B. C., McCauley, D. J., Cury, P. M., Duarte, C. M., Lubchenco, J., ... \& Castilla, J. C. (2017). Marine reserves can mitigate and promote adaptation to climate change. Proceedings of the National Academy of Sciences, 114(24), 6167-6175.

Roberts, J. M., Wheeler, A., Freiwald, A., \& Cairns, S. (2009). Cold-water corals: the biology and geology of deep-sea coral habitats. Cambridge University Press.

Rodrigo, C., Díaz, J., \& González-Fernández, A. (2014). Origin of the Easter Submarine Alignment: morphology and structural lineaments.

Rogers, A. D. (1994). The biology of seamounts. Advances in marine biology, 30, 305-350.

Rogers, A. D. (1999). The Biology of Lophelia pertusa (Linnaeus 1758) and Other Deep-Water Reef-Forming Corals and Impacts from Human Activities. International review of hydrobiology, 84(4), 315-406.

Rogers, A.D., Gianni, M. (2010) The Implementation of UNGA Resolutions 61/105 and 64/72 in the management of Deep-Sea fisheries on the high Seas. Report prepared for the Deep-Sea Conservation Coalition. International Programme on the State of the Ocean, London, United Kingdom, 97 pp.

Rooper, C. N., Zimmermann, M., Prescott, M. M., \& Hermann, A. J. (2014). Predictive models of coral and sponge distribution, abundance and diversity in bottom trawl surveys of the Aleutian Islands, Alaska. Marine Ecology Progress Series, 503, 157-176.

Rowden, A. A., Anderson, O. F., Georgian, S. E., Bowden, D. A., Clark, M. R., Pallentin, A., \& Miller, A. (2017). High-resolution habitat suitability models for the conservation and management of vulnerable marine ecosystems on the Louisville Seamount Chain, South Pacific Ocean. Frontiers in Marine Science, 4, 335.

Rowe, G. T., Morse, J., Nunnally, C., \& Boland, G. S. (2008). Sediment community oxygen consumption in the deep Gulf of Mexico. Deep Sea Research Part II: Topical Studies in Oceanography, 55(24-26), 2686-2691. 
1036

1037

1038

1039

1040

1041

1042

1043

1044

1045

1046

1047

1048

1049

1050

1051

1052

1053

1054

1055

1056

1057

1058

1059

1060

1061

1062

1063

1064

1065

1066

1067

1068

1069

1070

1071

1072

1073

1074

1075

1076

1077

1078

1079

Sandwell, D. T., Müller, R. D., Smith, W. H., Garcia, E., \& Francis, R. (2014). New global marine gravity model from CryoSat-2 and Jason-1 reveals buried tectonic structure. Science, 346(6205), 65-67.

Sappington, J. M., Longshore, K. M., \& Thompson, D. B. (2007). Quantifying landscape ruggedness for animal habitat analysis: a case study using bighorn sheep in the Mojave Desert. The Journal of wildlife management, 71(5), 1419-1426.

Segal MR. Machine learning benchmarks and random forest regression.

Sellanes, J., Salisbury, R. A., Tapia, J. M., \& Asorey, C. M. (2019). A new species of Atrimitra Dall, 1918 (Gastropoda: Mitridae) from seamounts of the recently created NazcaDesventuradas Marine Park, Chile. PeerJ, 7, e8279.

Serratosa, J., Hyrenbach, K. D., Miranda-Urbina, D., Portflitt-Toro, M., Luna, N., \& LunaJorquera, G. (2020). Environmental drivers of seabird at-sea distribution in the Eastern South Pacific Ocean: assemblage composition across a longitudinal productivity gradient. Frontiers in Marine Science, 6, 838.

Shepherd, B., Pinheiro, H. T., Phelps, T. A., Easton, E. E., Pérez-Matus, A., \& Rocha, L. A. (2020). A New Species of Chromis (Teleostei: Pomacentridae) from Mesophotic Coral Ecosystems of Rapa Nui (Easter Island) and Salas y Gómez, Chile. Copeia, 108(2), 326-332.

Shillinger, G. L., Palacios, D. M., Bailey, H., Bograd, S. J., Swithenbank, A. M., Gaspar, P., ... \& Block, B. A. (2008). Persistent leatherback turtle migrations present opportunities for conservation. PLoS Biol, 6(7), e171.

Smith, J. E., Schwarcz, H. P., Risk, M. J., McConnaughey, T. A., \& Keller, N. (2000). Paleotemperatures from deep-sea corals: overcoming 'vital effects'. Palaios, 15(1), 25-32.

Steinacher, M., Joos, F., Frölicher, T. L., Plattner, G. K., \& Doney, S. C. (2009). Imminent ocean acidification in the Arctic projected with the NCAR global coupled carbon cycle-climate model. Biogeosciences, 6(4), 515-533.

Steinberger, B. (2002). Motion of the Easter hot spot relative to Hawaii and Louisville hot spots. Geochemistry, Geophysics, Geosystems, 3(11), 1-27.

Syfert, M. M., Smith, M. J., \& Coomes, D. A. (2013). The effects of sampling bias and model complexity on the predictive performance of MaxEnt species distribution models. PloS one, $8(2)$, e55158.

Thiel, M., Luna-Jorquera, G., Álvarez-Varas, R., Gallardo, C., Hinojosa, I. A., Luna, N., ... \& Zavalaga, C. (2018). Impacts of marine plastic pollution from continental coasts to subtropical gyres - fish, seabirds, and other vertebrates in the SE Pacific. Frontiers in Marine Science, 5, 238.

Thresher, R. E., Tilbrook, B., Fallon, S., Wilson, N. C., \& Adkins, J. (2011). Effects of chronic low carbonate saturation levels on the distribution, growth and skeletal chemistry of deepsea corals and other seamount megabenthos. Marine Ecology Progress Series, 442, 87-99.

Thuiller, W., Georges, D., Engler, R., Breiner, F., Georges, M. D., \& Thuiller, C. W. (2016). Package 'biomod2'. Species distribution modeling within an ensemble forecasting framework. Ecography, 32, 369-373.

Tian, R. M., Sun, J., Cai, L., Zhang, W. P., Zhou, G. W., Qiu, J. W., \& Qian, P. Y. (2016). The deep-sea glass sponge Lophophysema eversa harbours potential symbionts responsible for the nutrient conversions of carbon, nitrogen and sulfur. Environmental microbiology, 18(8), 2481-2494.

Peer) reviewing PDF | (2021:02:58211:1:1:NEW 14 Jul 2021) 
1080

1081

1082

1083

1084

1085

1086

1087

1088

1089

1090

1091

1092

1093

1094

1095

1096

1097

1098

1099

1100

1101

1102

1103

1104

1105

1106

1107

1108

1109

1110

1111

1112

1113

1114

1115

1116

1117

1118

1119

1120

1121

1122

1123

1124

Tingley, G., \& Dunn, M. R. (Eds.). (2018). Global review of orange roughy (Hoplostethus atlanticus), their fisheries, biology and management. Food and Agriculture Organization of the United Nations.

Tittensor, D. P., Baco, A. R., Brewin, P. E., Clark, M. R., Consalvey, M., Hall-Spencer, J., ... \& Rogers, A. D. (2009). Predicting global habitat suitability for stony corals on seamounts. Journal of Biogeography, 36(6), 1111-1128.

Tong, R., Purser, A., Guinan, J., \& Unnithan, V. (2013). Modeling the habitat suitability for deep-water gorgonian corals based on terrain variables. Ecological Informatics, 13, 123-132.

Ullah, H., Nagelkerken, I., Goldenberg, S. U., \& Fordham, D. A. (2018). Climate change could drive marine food web collapse through altered trophic flows and cyanobacterial proliferation. PLoS biology, 16(1), e2003446.

UNGA. (2007) Sustainable fisheries, including through the 1995 agreement for the implementation of the provisions of the United Nations convention on the law of the sea of 10 December 1982 relating to the conservation and management of straddling fish stocks and highly migratory fish stocks, and related instruments. Resolution 61/105.

Van den Hove, S., \& Moreau, V. (2007). Deep-sea Biodiversity and Ecosystems: A Scoping Report on Their Socio-economy, Management and Governanace (No. 184). UNEP/Earthprint.

Van Dover, C. L., Ardron, J. A., Escobar, E., Gianni, M., Gjerde, K. M., Jaeckel, A., ... \& Weaver, P. P. E. (2017). Biodiversity loss from deep-sea mining. Nature Geoscience, 10(7), 464-465.

Van Dover, C. L., Aronson, J., Pendleton, L., Smith, S., Arnaud-Haond, S., Moreno-Mateos, D., ... \& Warner, R. (2014). Ecological restoration in the deep sea: Desiderata. Marine Policy, 44, 98-106.

Vierod, A. D., Guinotte, J. M., \& Davies, A. J. (2014). Predicting the distribution of vulnerable marine ecosystems in the deep sea using presence-background models. Deep Sea Research Part II: Topical Studies in Oceanography, 99, 6-18.

Visalli, M. E., Best, B. D., Cabral, R. B., Cheung, W. W., Clark, N. A., Garilao, C., ... \& McCauley, D. J. (2020). Data-driven approach for highlighting priority areas for protection in marine areas beyond national jurisdiction. Marine Policy, 122, 103927.

Von Dassow, P., Collado-Fabbri, S. (2014). Biological oceanography, biogeochemical cycles, and pelagic ecosystem functioning of the east-central South Pacific Gyre: focus on Easter Island and Salas y Gómez Island. Latin American Journal of Aquatic Research 42: 703-742.

Wagner, D., Friedlander, A. M., Pyle, R. L., Brooks, C. M., Gjerde, K. M., \& Wilhelm, T. A. (2020). Coral reefs of the high seas: hidden biodiversity hotspots in need of protection. Frontiers in Marine Science, 7, 776.

Wagner, D., van der Meer, L., Gorny, M., Sellanes, J., Gaymer, C. F., Soto, E. H., ... \& Morgan, L. E. (2021). The Salas y Gómez and Nazca ridges: A review of the importance, opportunities and challenges for protecting a global diversity hotspot on the high seas. Marine Policy, 126, 104377.

Wagner, H., Purser, A., Thomsen, L., Jesus, C. C., \& Lundälv, T. (2011). Particulate organic matter fluxes and hydrodynamics at the Tisler cold-water coral reef. Journal of Marine Systems, 85(1-2), 19-29.

Walbridge, S., Slocum, N., Pobuda, M., \& Wright, D. J. (2018). Unified geomorphological analysis workflows with Benthic Terrain Modeler. Geosciences, 8(3), 94. 
1125

1126

1127

1128

1129

1130

1131

1132

1133

1134

1135

1136

1137

1138

1139

1140

1141

1142

1143

1144

1145

1146

1147

1148

1149

1150

1151

1152

1153

1154

1155

1156

1157

1158

1159

1160

1161

1162

1163

1164

1165

1166

1167

1168

1169
Wall, M., Ragazzola, F., Foster, L. C., Form, A., \& Schmidt, D. N. (2015). Enhanced pH upregulation enables the cold-water coral Lophelia pertusa to sustain growth in aragonite undersaturated conditions. Biogeosciences Discussions, 12(17).

Watling, L., \& Norse, E. A. (1998). Disturbance of the seabed by mobile fishing gear: a comparison to forest clearcutting. Conservation Biology, 12(6), 1180-1197.

Weichler, T., Garthe, S., Luna-Jorquera, G., \& Moraga, J. (2004). Seabird distribution on the Humboldt Current in northern Chile in relation to hydrography, productivity, and fisheries. ICES Journal of Marine Science, 61(1), 148-154.

Weisz, J. B., Lindquist, N., \& Martens, C. S. (2008). Do associated microbial abundances impact marine demosponge pumping rates and tissue densities?. Oecologia, 155(2), 367-376.

Whitney, F., Conway, K., Thomson, R., Barrie, V., Krautter, M., \& Mungov, G. (2005). Oceanographic habitat of sponge reefs on the Western Canadian Continental Shelf. Continental Shelf Research, 25(2), 211-226.

Wild, C., Mayr, C., Wehrmann, L., Schöttner, S., Naumann, M., Hoffmann, F., \& Rapp, H. T. (2008). Organic matter release by cold water corals and its implication for fauna-microbe interaction. Marine Ecology Progress Series, 372, 67-75.

Wiley, E. O., McNyset, K. M., Peterson, A. T., Robins, C. R., \& Stewart, A. M., (2003). Niche modeling and geographic range predictions in the marine environment using a machine learning algorithm. Oceanography, 16(3), 120-127.

Williams, B., Risk, M. J., Ross, S. W., \& Sulak, K. J. (2006). Deep-water antipatharians: proxies of environmental change. Geology, 34(9), 773-776.

Winship, A. J., Thorson, J. T., Clarke, M. E., Coleman, H. M., Costa, B., Georgian, S. E., ... \& Whitmire, C. E. (2020). Good practices for species distribution modeling of deep-sea corals and sponges for resource management: data collection, analysis, validation, and communication. Frontiers in Marine Science.

Wood, S., \& Wood, M. S. (2015). Package 'mgcv'. R package version, 1, 29.

Wood, S.N. (2017) Generalized Additive Models: An Introduction with R (2nd edition). $\mathrm{CRC} /$ Taylor \& Francis.

Yahel, G., Whitney, F., Reiswig, H. M., Eerkes-Medrano, D. I., \& Leys, S. P. (2007). In situ feeding and metabolism of glass sponges (Hexactinellida, Porifera) studied in a deep temperate fjord with a remotely operated submersible. Limnology and oceanography, 52(1), 428-440.

Yáñez, E., Silva, C., Vega, R., Espíndola, F., Álvarez, L., Silva, N., .. \& Ramírez, N. (2009). Seamounts in the southeastern Pacific Ocean and biodiversity on Juan Fernandez seamounts, Chile. Latin American Journal of Aquatic Research, 37(3), 555-570.

Yesson, C., Bedford, F., Rogers, A. D., \& Taylor, M. L. (2017). The global distribution of deepwater Antipatharia habitat. Deep Sea Research Part II: Topical Studies in Oceanography, $145,79-86$.

Yesson, C., Taylor, M. L., Tittensor, D. P., Davies, A. J., Guinotte, J., Baco, A., ... \& Rogers, A. D. (2012). Global habitat suitability of cold-water octocorals. Journal of Biogeography, 39(7), 1278-1292.

Zweng, M. M., Reagan, J. R., Antono, J. I., Locarnini, R. A., Mishonov, A. V., Boyer, T. P., Garcia, HE, Baranova, O. K., Johnson, D. R., Seidov, D., Biddle, M.M. (2013). World Ocean Atlas 2013, Volume 2: Salinity. Eds: Levitus S, Mishonov A. NOAA Atlas NESDIS 74. $39 \mathrm{pp}$. 


\section{Table $\mathbf{1}$ (on next page)}

Environmental variables used in model creation.

Not all variables were retained in the final models produced. 'Reference' refers to either the tool used to create the variable (terrain metrics) or the original data source (other variables). 


\begin{tabular}{|c|c|c|c|c|}
\hline Variable name & $\begin{array}{l}\text { Included in } \\
\text { Final Models }\end{array}$ & Units & $\begin{array}{l}\text { Native } \\
\text { Resolution }\end{array}$ & Reference \\
\hline Bathymetry & & meters & $0.0083^{\circ}$ & $\begin{array}{l}\text { Becker et al. } 2009 \\
\text { Sandwell et al. } 2014\end{array}$ \\
\hline $\begin{array}{l}\text { Terrain Metrics } \\
\text { Aspect - Eastness } \\
\text { Aspect - Northness } \\
\text { Curvature - General } \\
\text { Curvature - Cross-Sectional } \\
\text { Curvature - Longitudinal }\end{array}$ & & & $\begin{array}{l}0.0083^{\circ} \\
0.0083^{\circ} \\
0.0083^{\circ} \\
0.0083^{\circ} \\
0.0083^{\circ}\end{array}$ & $\begin{array}{l}\text { Jenness 2013a } \\
\text { Jenness 2013a } \\
\text { Jenness 2013a } \\
\text { Jenness 2013a } \\
\text { Jenness 2013a }\end{array}$ \\
\hline $\begin{array}{l}\text { Roughness } \\
\text { Slope } \\
\text { Topographic Position Index (TPI) } \\
\text { Vector Ruggedness Measure (VRM) }\end{array}$ & $\begin{array}{l}X \\
X \\
X\end{array}$ & degrees & $\begin{array}{l}0.0083^{\circ} \\
0.0083^{\circ} \\
0.0083^{\circ}\end{array}$ & $\begin{array}{l}\text { Jenness } 2013 a \\
\text { Jenness } 2013 a \\
\text { Jenness } 2013 b\end{array}$ \\
\hline $\begin{array}{l}\text { Geomorphological Features } \\
\text { Seamount } \\
\text { Guyot } \\
\text { Canyon } \\
\text { Ridge } \\
\text { Spreading Ridge } \\
\text { Plateaus } \\
\text { Escarpment }\end{array}$ & & & & $\begin{array}{l}\text { Harris et al. } 2014 \\
\text { Harris et al. } 2014 \\
\text { Harris et al. } 2014 \\
\text { Harris et al. } 2014 \\
\text { Harris et al. } 2014 \\
\text { Harris et al. } 2014 \\
\text { Harris et al. } 2014\end{array}$ \\
\hline \multicolumn{5}{|l|}{ Benthic Conditions } \\
\hline Total alkalinity & & $\mu \mathrm{mol} \mathrm{l^{-1 }}$ & $3.6 \mathrm{x} 0.8-1.8^{\circ}$ & Steinacher et al. (2009) \\
\hline $\begin{array}{l}\text { Dissolved inorganic carbon } \\
\text { Omega aragonite }\left(\Omega_{\mathrm{A}}\right)\end{array}$ & $\mathrm{X}$ & $\mu \mathrm{mol} \mathrm{1} \mathrm{l}^{-1}$ & $\begin{array}{l}3.6 \times 0.8-1.8^{\circ} \\
3.6 \times 0.8-1.8^{\circ}\end{array}$ & $\begin{array}{l}\text { Steinacher et al. (2009) } \\
\text { Steinacher et al. (2009) }\end{array}$ \\
\hline Omega calcite $\left(\Omega_{\mathrm{C}}\right)$ & & & $3.6 \times 0.8-1.8^{\circ}$ & Steinacher et al. (2009) \\
\hline Dissolved oxygen & $\mathrm{X}$ & $\mathrm{ml} \mathrm{l}^{-1}$ & $1^{\circ}$ & Garcia et al. 2014a \\
\hline Salinity & & pss & $0.25^{\circ}$ & Zweng et al. 2013 \\
\hline Temperature & & ${ }^{\circ} \mathrm{C}$ & $0.25^{\circ}$ & Locarnini et al. 2013 \\
\hline Phosphate & $X$ & $\mu \mathrm{mol} \mathrm{l} \mathrm{l}^{-1}$ & $1^{\circ}$ & Garcia et al. 2014b \\
\hline Silicate & $X$ & $\mu \mathrm{mol} \mathrm{l} \mathrm{l}^{-1}$ & $1^{\circ}$ & Garcia et al. $2014 b$ \\
\hline Nitrate & $X$ & $\mu \mathrm{mol} \mathrm{l} \mathrm{l}^{-1}$ & $1^{\circ}$ & Garcia et al. 2014b \\
\hline Particulate organic carbon (POC) & $\mathrm{X}$ & $\begin{array}{l}\mathrm{g} \mathrm{C} \mathrm{m}^{-2} \\
\mathrm{yr}^{-1}\end{array}$ & $0.05^{\circ}$ & Lutz et al. (2007) \\
\hline Regional current velocity & & $\mathrm{m} \mathrm{s}^{-1}$ & $0.5^{\circ}$ & Carton et al. (2005) \\
\hline Vertical current velocity & & $\mathrm{m} \mathrm{s}^{-1}$ & $0.5^{\circ}$ & Carton et al. (2005) \\
\hline \multicolumn{5}{|l|}{ Surface Conditions } \\
\hline Chlorophyll $a$ & & $\mathrm{mg} \mathrm{m}^{-3}$ & $4 \mathrm{~km}$ & Aqua Modis (NOAA) \\
\hline Sea Surface Temperature & & ${ }^{\circ} \mathrm{C}$ & $4 \mathrm{~km}$ & Aqua Modis (NOAA) \\
\hline
\end{tabular}




\section{Table 2 (on next page)}

Model performance as evaluated by the AUC, kappa, and TSS metrics.

Higher values (closer to one) indicate better model performance in each metric. Each metric was calculated using test data during a ten-fold cross-validation procedure withholding $20 \%$ of records for testing, and also for the full model using all available training data. Test value are given as the mean \pm standard deviation across 10 model runs. 


\begin{tabular}{|c|c|c|c|c|c|}
\hline \multirow[b]{2}{*}{ Taxa } & \multirow[b]{2}{*}{ Model } & \multicolumn{2}{|c|}{ Test Data } & \multicolumn{2}{|c|}{ Training Data } \\
\hline & & AUC & TSS & AUC & TSS \\
\hline \multirow[t]{5}{*}{ Demosponges } & BRT & $0.939 \pm 0.02$ & $0.783 \pm 0.04$ & 0.937 & 0.799 \\
\hline & GAM & $0.976 \pm 0.01$ & $0.912 \pm 0.03$ & 0.974 & 0.799 \\
\hline & Maxent & $0.975 \pm 0.03$ & $0.625 \pm 0.06$ & 0.817 & 0.524 \\
\hline & $\mathrm{RF}$ & $0.837 \pm 0.01$ & $0.932 \pm 0.03$ & 0.998 & 0.959 \\
\hline & Ensemble & - & - & 0.988 & 0.916 \\
\hline \multirow[t]{5}{*}{ Glass Sponges } & BRT & $0.868 \pm 0.02$ & $0.718 \pm 0.04$ & 0.872 & 0.739 \\
\hline & GAM & $0.904 \pm 0.04$ & $0.770 \pm 0.05$ & 0.929 & 0.763 \\
\hline & Maxent & $0.902 \pm 0.04$ & $0.738 \pm 0.06$ & 0.904 & 0.679 \\
\hline & $\mathrm{RF}$ & $0.948 \pm 0.04$ & $0.862 \pm 0.07$ & 0.993 & 0.961 \\
\hline & Ensemble & - & - & 0.968 & 0.770 \\
\hline \multirow[t]{5}{*}{ Stony Corals } & BRT & $0.915 \pm 0.03$ & $0.821 \pm 0.07$ & 0.924 & 0.842 \\
\hline & GAM & $0.956 \pm 0.03$ & $0.827 \pm 0.06$ & 0.964 & 0.855 \\
\hline & Maxent & $0.931 \pm 0.03$ & $0.820 \pm 0.06$ & 0.939 & 0.822 \\
\hline & $\mathrm{RF}$ & $0.965 \pm 0.02$ & $0.901 \pm 0.04$ & 0.980 & 0.940 \\
\hline & Ensemble & - & - & 0.973 & 0.845 \\
\hline
\end{tabular}




\section{Table 3 (on next page)}

Percent variable contributions to each model.

$\Omega_{A}$ was only included in stony coral models. Silicate was only included in demosponge and glass sponge models. POC=particulate organic carbon. TPI-40,000=topographic position index calculated at the 40,000 m scale. VRM-21=vector ruggedness measure calculated with a neighborhood size of 21 . The top three variables for each model are highlighted in bold. 


\begin{tabular}{lllllllllll}
\hline Taxa & Model & $\boldsymbol{\Omega}_{\mathrm{A}}$ & $\begin{array}{l}\text { Dissolved } \\
\text { Oxygen }\end{array}$ & Nitrate & Phosphate & POC & Silicate & Slope & $\begin{array}{l}\text { TPI- } \\
40,000\end{array}$ & $\begin{array}{l}\text { VRM- } \\
21\end{array}$ \\
\hline Demosponges & BRT & - & 0.0 & 0.4 & 0.3 & $\mathbf{3 . 7}$ & $\mathbf{8 . 5}$ & 0.1 & $\mathbf{8 6 . 0}$ & 1.0 \\
& GAM & - & $\mathbf{1 9 . 0}$ & 15.9 & 4.2 & $\mathbf{1 6 . 7}$ & $\mathbf{2 7 . 4}$ & 3.8 & 7.4 & 5.6 \\
& Maxent & - & 0.0 & 0.0 & 2.4 & $\mathbf{1 9 . 3}$ & 0.2 & 2.3 & $\mathbf{5 0 . 4}$ & $\mathbf{2 5 . 4}$ \\
& RF & - & 0.6 & 4.5 & 5.8 & 6.5 & $\mathbf{3 5 . 5}$ & 1.9 & $\mathbf{3 7 . 4}$ & $\mathbf{7 . 7}$ \\
Glass Sponges & BRT & - & 0.1 & 0.3 & 0.1 & $\mathbf{1 2 . 5}$ & $\mathbf{7 8 . 3}$ & $\mathbf{7 . 3}$ & 0.6 & 0.9 \\
& GAM & - & 0.9 & $\mathbf{8 . 5}$ & $\mathbf{2 5 . 7}$ & 3.3 & $\mathbf{5 2 . 5}$ & 5.0 & 3.5 & 0.6 \\
& Maxent & - & 3.2 & 3.5 & 0.8 & 1.0 & $\mathbf{6 2 . 8}$ & $\mathbf{1 1 . 8}$ & 4.3 & $\mathbf{1 2 . 7}$ \\
& RF & - & 3.5 & 5.7 & 7.9 & $\mathbf{2 6 . 8}$ & $\mathbf{3 1 . 1}$ & $\mathbf{1 3 . 6}$ & 7.5 & 3.9 \\
Stony Corals & BRT & $\mathbf{8 0 . 3}$ & 0.1 & 0.1 & 0.0 & 0.4 & - & 0.3 & $\mathbf{1 8 . 1}$ & $\mathbf{0 . 6}$ \\
& GAM & $\mathbf{4 8 . 9}$ & 1.0 & 1.6 & $\mathbf{3 7 . 4}$ & $\mathbf{5 . 2}$ & - & 0.5 & 2.4 & 2.9 \\
& Maxent & $\mathbf{8 9 . 7}$ & 0.1 & 0.0 & 0.0 & $\mathbf{4 . 8}$ & - & 0.3 & 0.0 & $\mathbf{5 . 1}$ \\
& RF & $\mathbf{5 4 . 1}$ & 2.2 & $\mathbf{7 . 0}$ & 3.2 & 1.6 & - & 1.1 & $\mathbf{2 8 . 6}$ & 2.2 \\
\hline
\end{tabular}


Figure 1

Map of the study area.

The map shows the modeling extent, distribution of occurrence records for demosponges, glass sponges, and stony corals, national exclusive economic zones (EEZs), and Ecologically or Biologically Significant Marine Area (EBSA) designation.

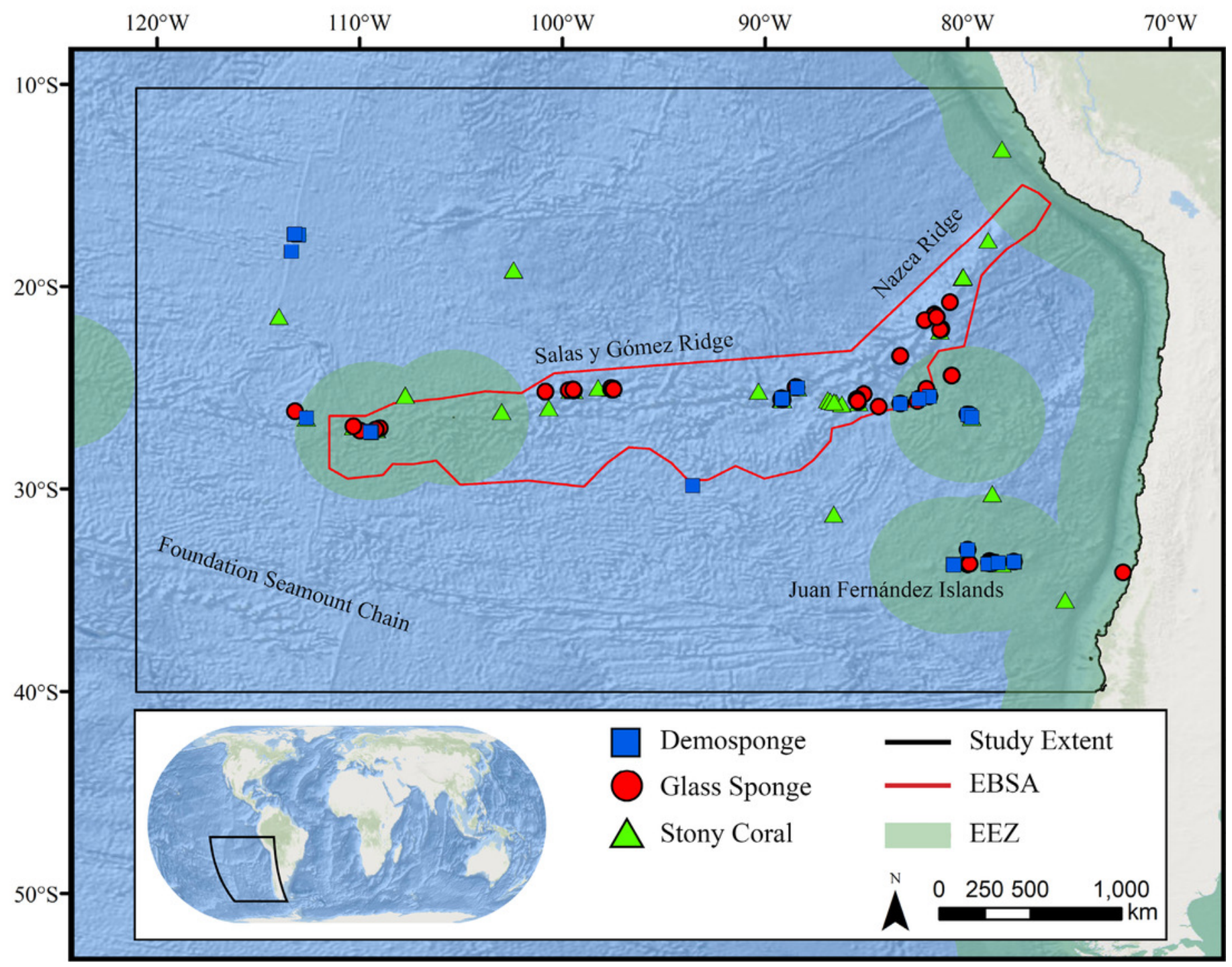




\section{Figure 2}

Relationship among the final set of environmental variables used to train the models.

Depth was excluded from the final models but was included here for reference. Silicate was only included for demosponges and glass sponges. $\Omega_{\mathrm{A}}$ was only included for stony corals.

Left: Pearson's correlation coefficients among variables. Right: Cluster dendrogram showing the conceptual relationship among variables, with variables containing similar information clustering closer together. See Supplemental Figures 1 and 2 for the correlations and clustering of all environmental variables considered for modeling.

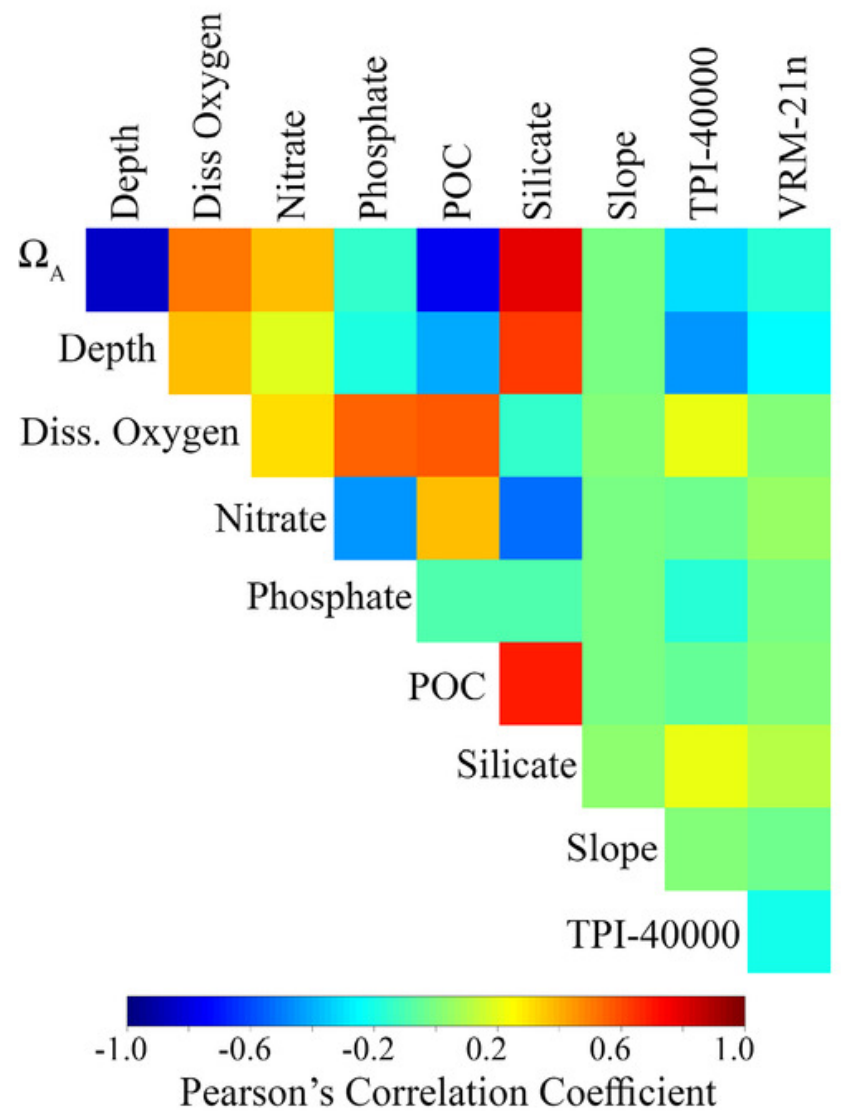

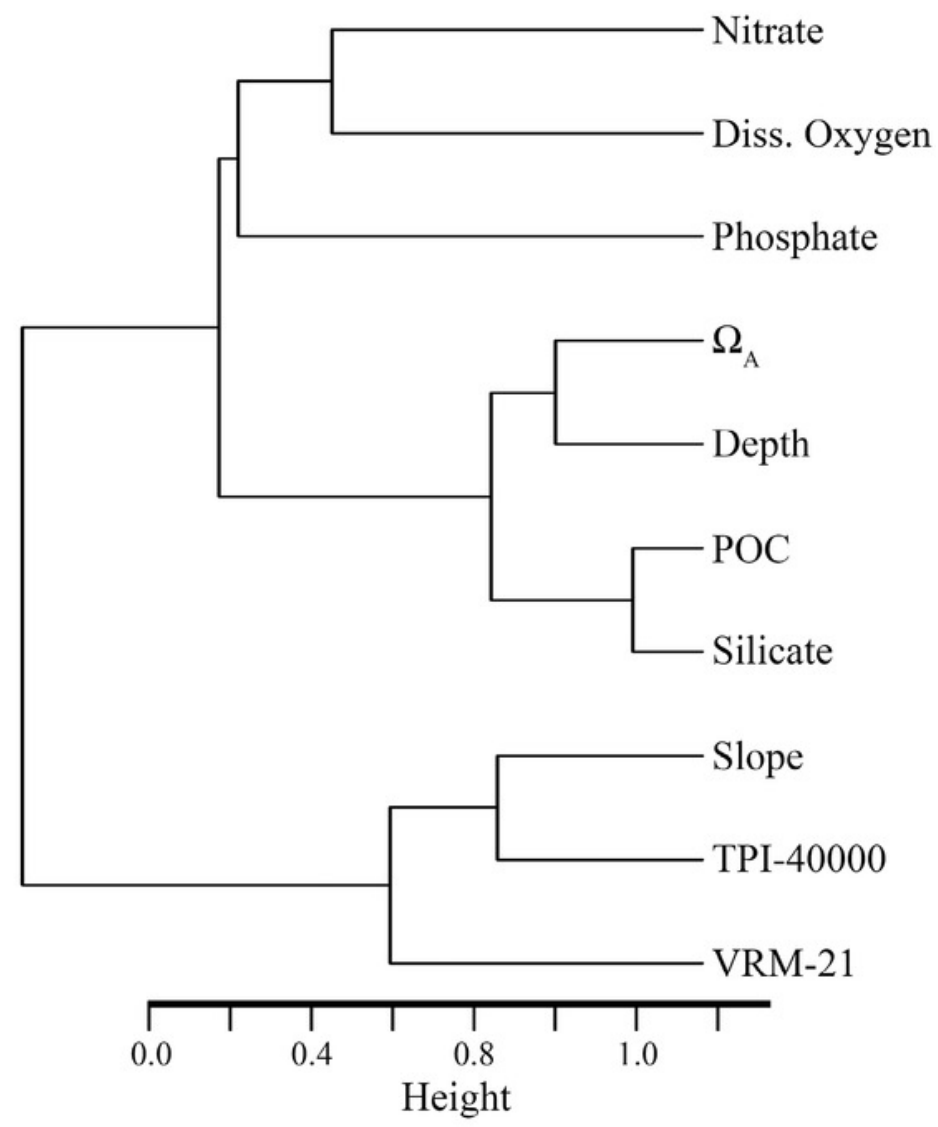


Figure 3

Predicted habitat suitability for the demosponge ensemble model.

Warmer colors indicate more suitable habitat.

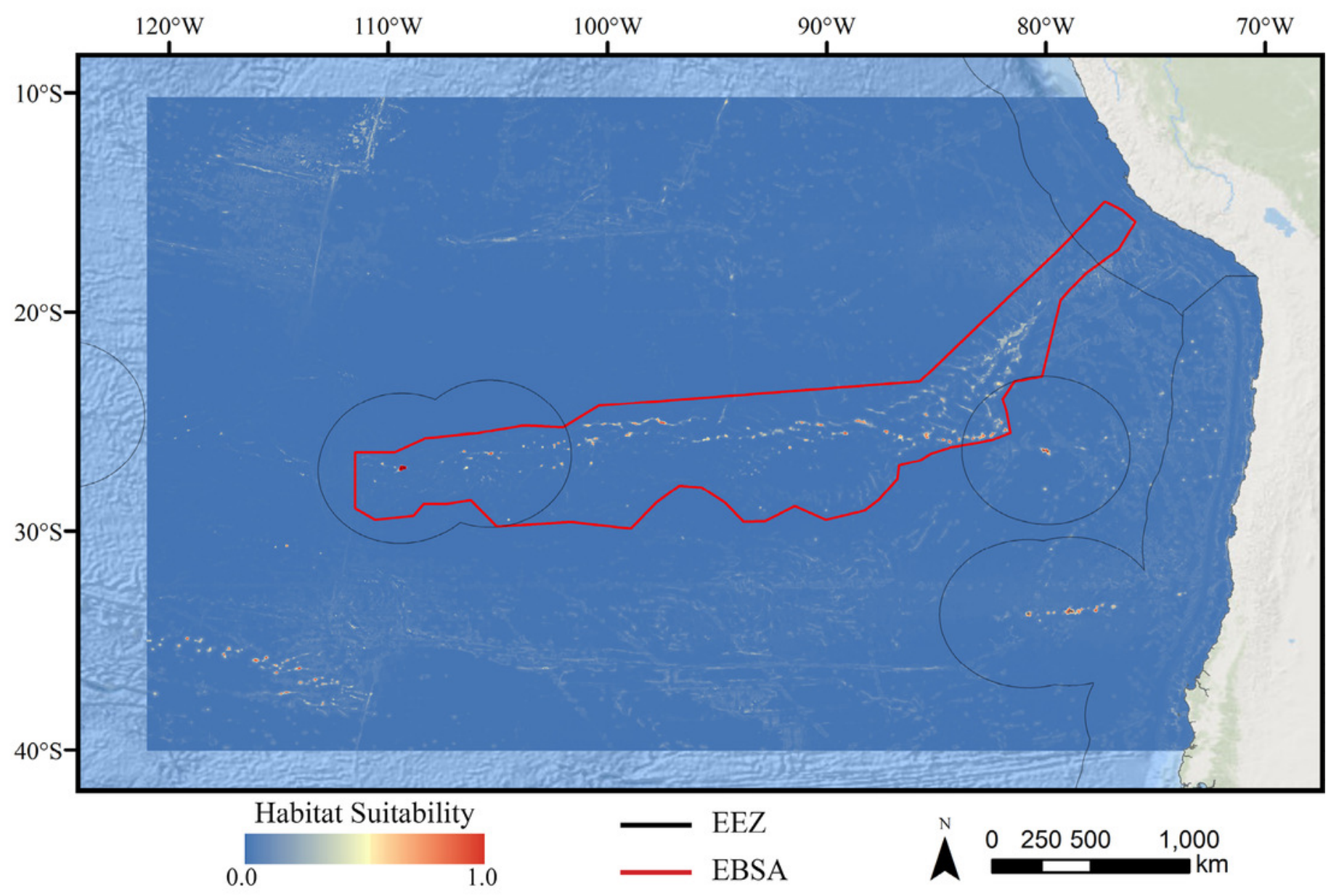


Figure 4

Predicted habitat suitability for the glass sponge ensemble model.

Warmer colors indicate more suitable habitat.

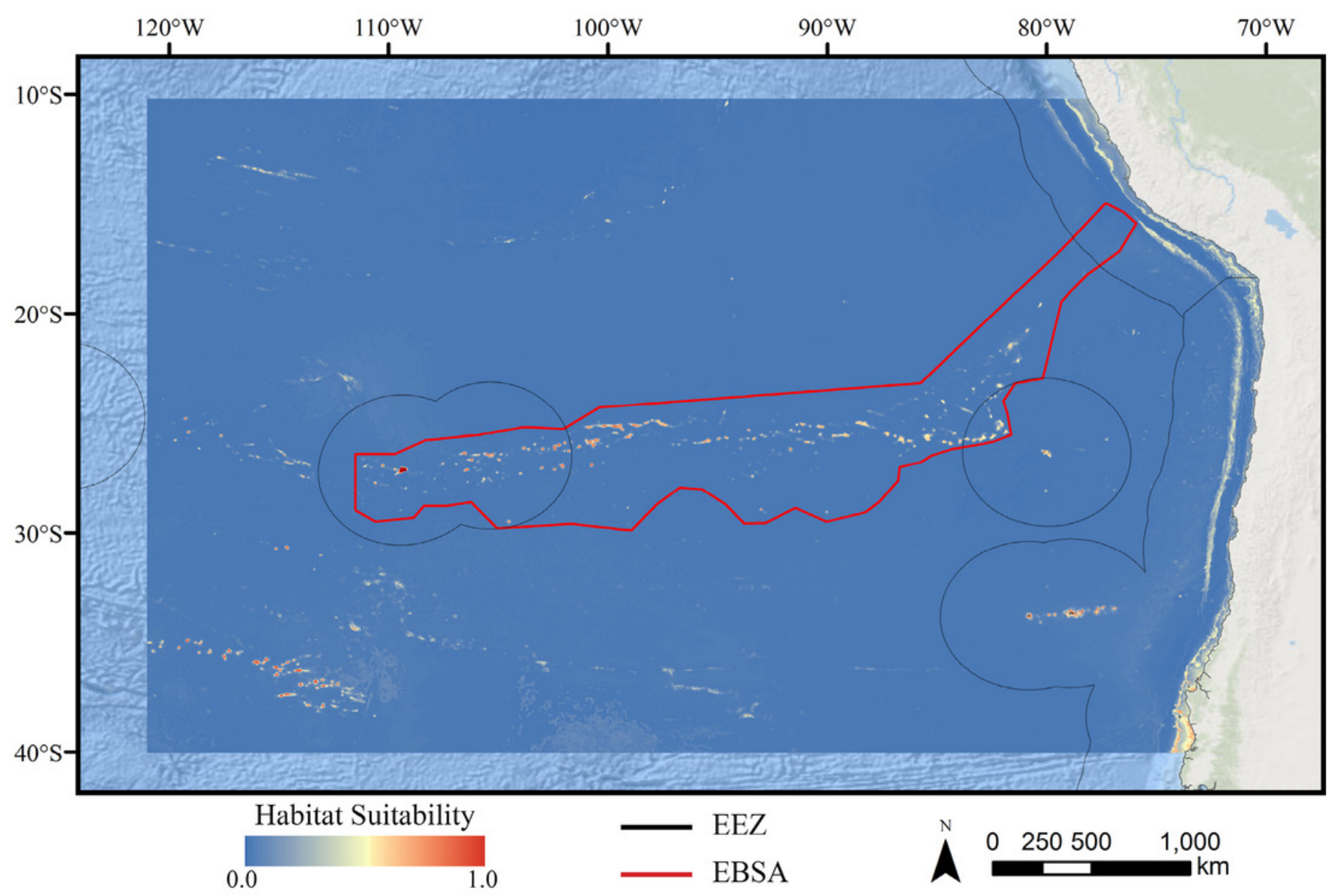




\section{Figure 5}

Predicted habitat suitability for the stony coral ensemble model.

Warmer colors indicate more suitable habitat.

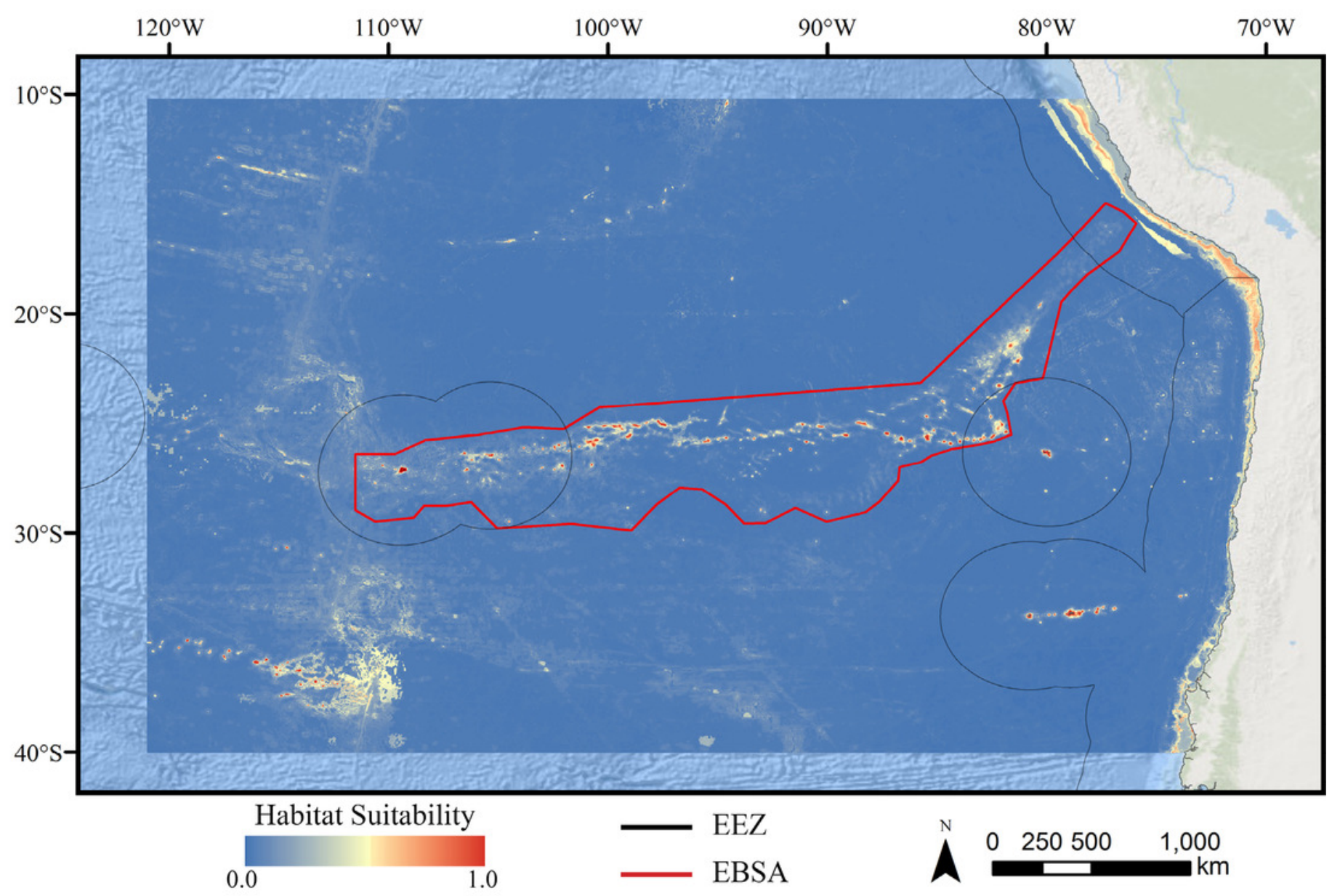




\section{Figure 6}

Ensemble models for demosponges, glass sponges, and stony corals showing a subset of highly suitable seamounts on the western side of the Salas y Gómez Ridge.

Depth with 500 m contours is shown in the last panel for reference.
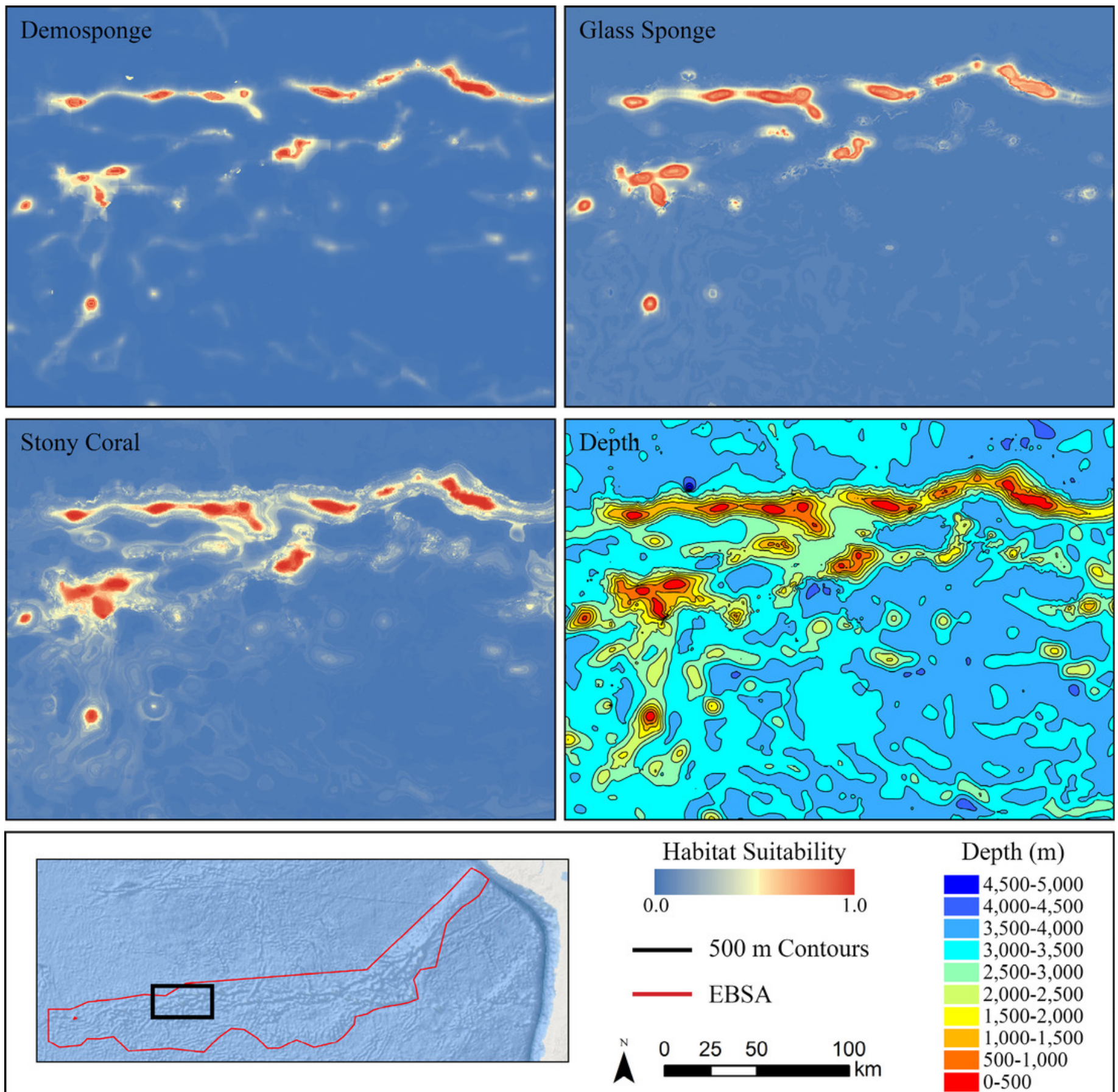

Depth (m)

4,500-5,000 $4,000-4,500$ $3,500-4,000$ $3,000-3,500$ $2,500-3,000$ $2,000-2,500$ $1,500-2,000$ 1,000-1,500 $500-1,000$ $0-500$ 


\section{Figure 7}

Response curves showing how the model fit changes over the range of each environmental variable.

Values were calculated for the final variable set using the ensemble model for each taxa.

Silicate was only included in demosponge and glass sponge models, and $\Omega_{A}$ was only included in the stony coral model. 

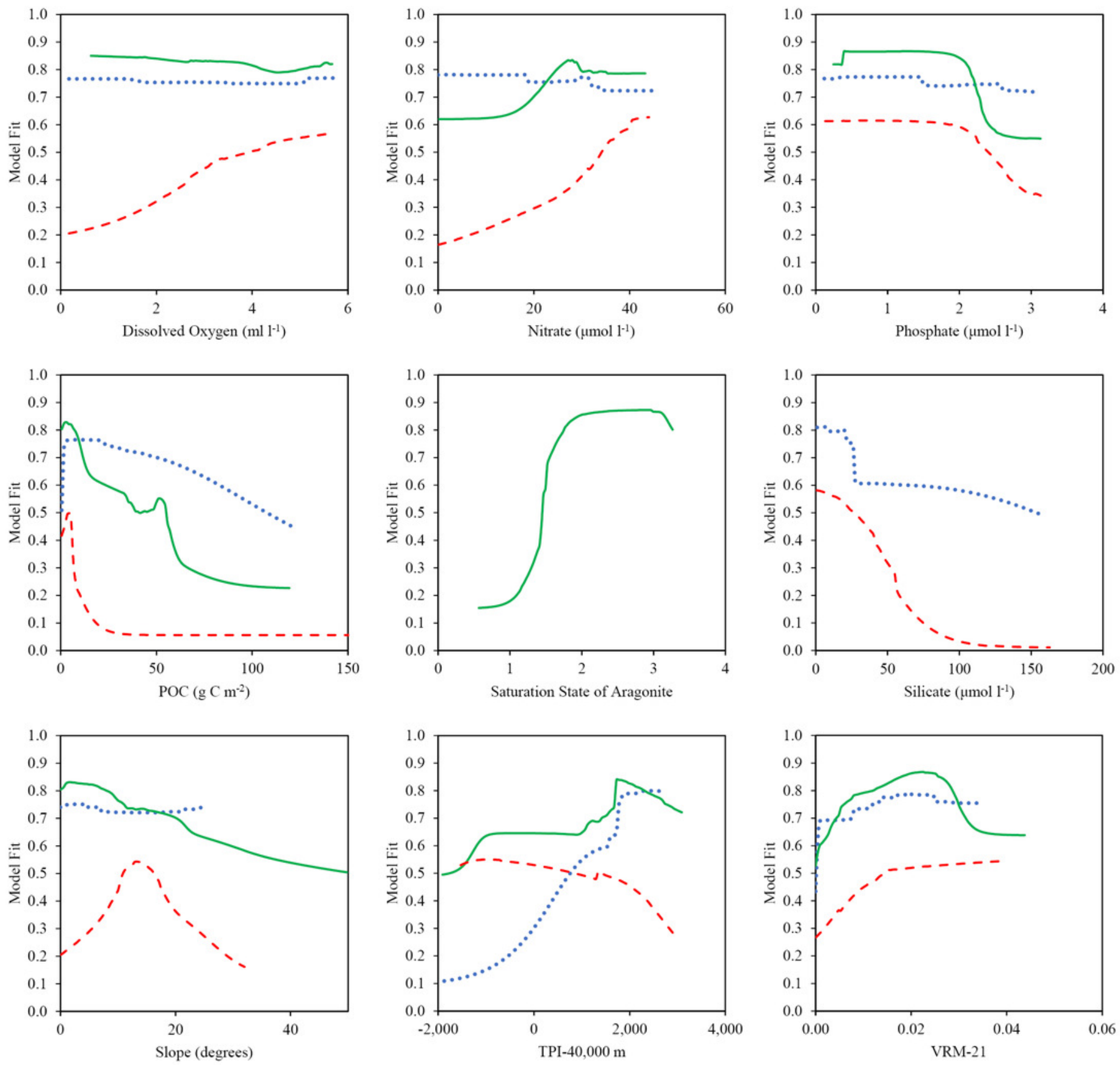

$\cdots$ Demosponge $\quad$ - - - Glass Sponge

Stony Coral 